This is a preprint that has not been peer-reviewed yet (2021-12-30).

Feedback related to the typology, non-cited relevant literature, or suggestions for suitable research outlets, are very welcome.

\title{
A new typology of psychological mechanisms underlying prosocial decisions
}

Arvid Erlandsson, Hajdi Moche and Stephan Dickert

Corresponding author arvid.erlandsson@liu.se

\begin{abstract}
Charitable giving, volunteering, climate-friendly choices, and most recently changing one's lifestyle to stop the spread of the coronavirus are all examples of prosocial behavior. Prosociality can be investigated from different perspectives including the "who-question" (which people are more likely to help), and the "when-question" (which situational factors stimulate helping?), but in this article we focus primarily on the "why-question" (which emotions and cognitions motivate helping?)

Specifically, this article tries to organize and synthesize literature related to emotions, thoughts, and beliefs (i.e. psychological mechanisms) that motivate or demotivate human helping behavior. To do this, we present a new typology including four overarching interrelated categories, each encompassing multiple subcategories.
\end{abstract}

(1) Emotions: (a) emotional reactions elicited by the need situation such as empathic concern/sympathy, (b) positive or negative attitudes toward the beneficiary or the requester, (c) incidental mood.

(2) Moral principles: (a) personal responsibility, (b) fairness-concerns, (c) aversion towards causing harm.

(3) Anticipated impact: (a) self-efficacy (e.g. “can I make a difference?”) and (b) response-efficacy (e.g., "is this cause/project efficient and worthwhile?").

(4) Anticipated personal consequences: (a) material, (b) social and (c) emotional costs and benefits that the helper expects will follow if she helps or if she does not help.

Increased knowledge about the "who" (e.g. individual differences in demography or personality) and "when" (situational antecedents such as characteristic of those in need, or type of solicitation) can surely help predict and even increase prosociality, but we argue that to understand the psychology of helping we need to also consider the psychological mechanisms underlying prosocial decisions (the "why-question").

We compare our typology against related theoretical frameworks, and present the pros and cons with different methodological approaches of testing psychological mechanisms of helping, with the aim to help researchers and practitioners better organize and understand the many psychological factors that influence prosocial decisions.

Keywords: Psychological mechanisms of helping; Prosocial motivation; Emotional reactions; Moral principles; Altruism; Perceived impact; Egoistic motives; Emphatic concern; Emotion regulation; Impression management; Anticipated costs and benefits

Acknowledgement: The authors thank the JEDI-Lab and especially Per A. Andersson, Amanda Lindkvist and Daniel Västfjäll for constructive feedback. 


\section{Introduction}

The recent upsurge of research on prosocial behavior has led to a large number of emotions and cognitions being proposed as explanations for why some groups of people help more than others, and why some situations make us help more than others. The typology presented in this paper is intended to provide a conceptual overview of these emotions and cognitions and offer a tool to organize existing and future research about psychological mechanisms underlying helping, so that it becomes more comprehensible, as well as to generate testable hypotheses. The typology synthesizes and organizes psychological mechanisms that motivate or demotivate prosocial behavior, into four overarching, interrelated categories: (1) Emotions; (2) Moral principles; (3) Anticipated impact; (4) Anticipated personal consequences (see Figure 1).

We begin by explaining how "prosocial behavior" and "psychological mechanisms" should and should not be understood when reading this article. The second section introduces the typology and distinguishes the "why-question" of helping, from the "when-question", and the "who-question". Sections 3-6 describe each of the four overarching categories and their respective subcategories. Section 7 compares our typology against the eight mechanisms suggested in the influential paper by Bekkers and Wiepking (2011a). The final section discusses different methodological approaches when testing psychological mechanisms underlying prosocial decisions.

\section{Definitions}

\section{What is prosocial behavior?}

Prosocial behavior, or helping (we will use these terms interchangeably) is here used as an umbrella term for behaviors that imply some type of cost for the helper (the person doing the act), while improving (or at least intending to improve) the situation for the beneficiary. A beneficiary can be a single person or non-human animal in need, but also a group, an organization, or some larger entity (such as Planet Earth). The cost for the helper can vary in magnitude and involve money such as when giving to charitable organizations or panhandlers (Bhati \& Hansen, 2020; Lee \& Farrell, 2003; Oppenheimer \& Olivola, 2011; Zagefka \& James, 2015), or time such as when volunteering (Ferguson et al., 2019; Moseley et al., 2018). The cost could also involve personal discomfort or risk, such as when donating blood or organs (Ferguson \& Lawrence, 2016; Wang, 2011), or emergency helping such as saving someone from a fire (Latane \& Darley, 1970). Helping can also be done by "sacrificing personal enjoyment", such as abstaining from traveling by plane in order to help fight climate change (Sachdeva et al., 2015; Tobler et al., 2012;), or wearing a mask, adjusting one's way of living, and taking the vaccine, in order to help the fight against the novel coronavirus (Erlandsson, 2021a; Lunn et al., 2020; Vacondio et al., 2021).

\section{What are underlying psychological mechanisms?}

In this article, psychological mechanisms are referred to as conscious emotions, thoughts, or beliefs that influence helping decisions. ${ }^{1}$ Helping decisions can relate to how to distribute helping among different beneficiaries (allocations in helping dilemmas, Baron \& Szymanska, 2011; Erlandsson, 2020;

\footnotetext{
${ }^{1}$ That an emotion, thought, or belief is conscious does not imply that it is deliberate, only that the person experiencing it is aware of it to some extent. It can be argued that we sometimes help without any preceding conscious emotions, thoughts, or beliefs, but out of pure instinct, e.g. reacting immediately when someone falls, or automatically mimicking someone else's helping behavior. The typology is compatible with the idea that helping behavior sometimes occur without any intermediating psychological mechanisms (Clark \& Word, 1974).
} 
Erlandsson et al., 2020a), but in this article we focus primarily on the most typical helping decisions — whether to help or not (likelihood), and how much to help (magnitude; Dickert et al., 2011a). In this context, psychological mechanisms can be understood as emotions, thoughts or beliefs that motivate (increase) or demotivate (decrease) helping.

It should be clarified that underlying mechanisms of human behavior can be investigated on different levels (Preston \& de Waal, 2002). Evolutionary psychologists typically focus on the "ultimate causes" of human prosociality and explain prosocial behavior in terms of natural selection (Burnstein et al., 1994; Burum et al., 2020; Goetz et al., 2010; van Vugt \& van Lange, 2006), whereas medical scientists focus on biological or chemical mechanisms (e.g. oxytocin; de Dreu et al., 2010; 2011; Marsh et al., 2020), and neuroscientists investigate activation in certain brain areas when people respond to prosocial decisions (Cutler \& Campbell-Meiklejohn, 2019; Genevsky et al., 2013; Harbaugh et al., 2007; Mayr et al., 2009).

The different levels of analysis should be seen as complementary accounts. We are not denying the evolutionary origin of prosocial emotions, that increased activity in a specific brain area makes us experience these emotions, or that thoughts and beliefs are represented in the brain. Still, in this article we understand psychological mechanisms as emotions, thoughts, or beliefs that, in theory, could be measured by asking helpers to introspect e.g. why they helped or why they did not help in a specific situation (see Table 1). We emphasize "in theory" because self-reports come with several inherent flaws. People do not always have full access to, forget, or are not able to verbalize, all their reasons for their behaviors (Nisbett \& Wilson, 1977; Ross \& Nisbett, 2011). Also, even when people are aware of the reasons for their helping or non-helping, they tend to justify their decisions post-hoc so that they

appear more moral and socially acceptable than they actually are (Danioni \& Barni, 2021). We discuss these methodological issues further in Section 8.

\section{Four overarching categories}

We propose a typology with four overarching categories: (1) Emotions; (2) Moral principles; (3) Anticipated impact; and (4) Anticipated personal consequences. Each overarching category includes psychological mechanisms that increase (motivate) helping as well as mechanisms that decrease (demotivate) helping, and there are two or three subcategories within each category (see Figure 1 and Table 1). The mechanisms in the four overarching categories are interrelated and rarely experienced in isolation, but we argue that they can be distinguished theoretically as well as empirically and that all four can increase or decrease helping motivation independently of each other.

The overarching categories can be understood as four psychological strings (or decision processes), that one can play on in order to influence helping (the heart, head, book, and binoculars; loosely inspired by Weber, 1998; Weber et al., 2004; Weber \& Lindemann, 2007). Appealing to the heart means trying to increase helping by making people experience intense compassionate feelings (emotions, e.g. Slovic et al., 2017; Small, 2011), whereas appealing to the head implies trying to make people think that their helping would be effective and impactful (anticipated impact, e.g., Camilleri \& Larrick, 2019; Lewis \& Small, 2019). Further, appealing to the book implies trying to make people acknowledge a personal responsibility to help (moral principles, e.g., Everett et al., 2020; Goldstein et al., 2011), whereas appealing to the binoculars means trying to make people help by emphasizing the large personal benefits, or small personal costs, of helping (anticipated personal consequences, e.g. Feiler et al., 2012; White \& Peloza, 2009). Each motive can also be made more salient for participants through various priming techniques (e.g. Barth \& Stürmer, 2016; Oceja, 2008; Small et al., 2007).

The four overarching categories can be understood as a separate cell in a $2 * 2$ matrix (see Figure 1). The first dimension differentiates psychological mechanisms that are strongly linked to the helper 
(internal focus; Emotions and Anticipated Personal Consequences) from mechanisms that are primarily linked to something outside the helper such as the beneficiaries or the world as a whole (external focus; Moral principles and Anticipated impact). ${ }^{2}$ The second dimension differentiates psychological mechanisms that are inherently forward-looking and dependent on what the helper anticipates will happen if he/she helps or does not help (future-oriented; Anticipated Personal Consequences and Anticipated impact), from mechanisms that are determined more by what is experienced at the moment or what has happened previously (past or present-oriented; Emotions and Moral Principles).

Past or present-oriented

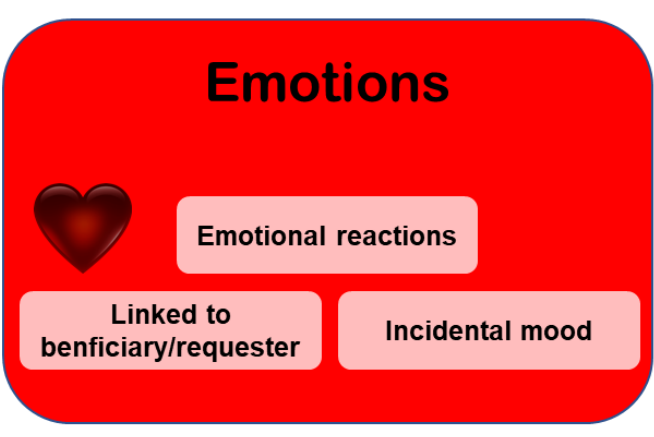

Moral principles

External focus
Internal

focus

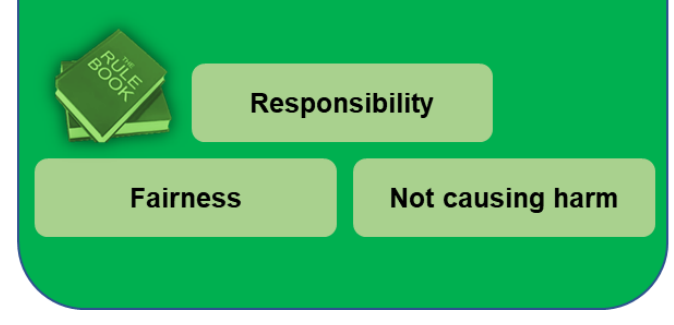

Future-oriented

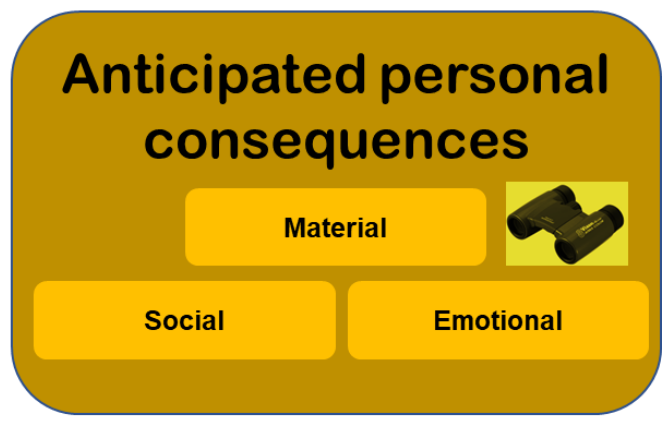

Anticipated impact

Self-efficacy

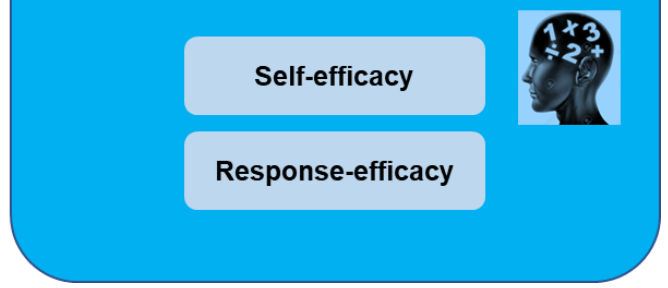

Figure 1: The four overarching categories and their respective subcategories of helping motives (including illustrative symbol) and how they differ on two dimensions.

\section{The who-, when- and why-questions}

This article distinguishes between three questions that are central in research on prosociality; "the Who?", "the When?" and "the Why?" (Bhati \& Hansen, 2020; Erlandsson, 2014).

The who-question is about which individual differences predict helping and whether some groups of people (e.g. women, educated, extroverts) help more than others (e.g. Bekkers \& Wiepking, 2011b; Wiepking \& Bekkers, 2012; see also Erlandsson et al., 2018a; Nilsson et al., 2016; 2020).

The when-question is about how different situational factors influence helping - for instance how a charity appeal is framed, the characteristics of those in need, or how a request for help is made - and how these situational differences increase or decrease helping (e.g. Erlandsson et al., 2016a;

\footnotetext{
2 "Internal vs. external" should not be understood as the same as "Egoistic vs. altruistic". Internally focused mechanisms can be both typically egoistic (e.g. anticipated material or social rewards if helping) or typically altruistic (e.g. feeling strong empathic concern). Likewise, external mechanisms can be perceived as very altruistic (e.g. a desire to help as many as possible) or as not altruistic at all (e.g. a perceived duty to comply with the moral rules or a desire to make a large personal impact). The distinction between altruistic and egoistic motives for helping has been important in most past literature about mechanisms underlying helping (e.g. Batson, 2011), but it is less central in this typology.
} 
Erlandsson et al., 2018b; Weyant, 1996). In our own research, we sometimes use the term "helpingeffects" to refer to situational factors that influence helping (Erlandsson, 2021b).

The why-question is instead about the psychological and motivational aspects of helping. It is about what goes on in our heads, and what types of feelings, thoughts, and beliefs that increase or decrease our helping. Understanding which situational and individual factors increase helping is certainly important and can help us predict the future, but understanding also which emotions, thoughts and beliefs best explain these increases adds an extra layer to our understanding of human prosociality (Butts et al., 2019; Cryder et al., 2013a; Dickert et al., 2016; Erlandsson et al., 2014; 2015; Lee et al., 2014).

The who-, the when- and the why-questions of helping are not always clearly separated in the literature. In one of the most ambitious reviews about prosocial behavior to date, Bekkers and Wiepking 2011a) suggested a theoretical framework including eight psychological mechanisms: (1) awareness of need, (2) solicitation, (3) cost \& benefits, (4) altruism, (5) reputation, (6) psychological benefits, (7) efficacy, and (8) values.

Bekkers and Wiepking did an outstanding job in summarizing literature on charitable giving from different fields, but we argue that they used an overly broad definition of psychological mechanisms, and mixed what we would refer to as individual differences (the who-question), situational differences (the when-question), and psychological mechanisms (the why-question). The typology that we suggest is inspired by, and has considerable overlap with the framework by Bekkers and Wiepking (2011a; 2011c), but focuses exclusively on the why-question of helping. We compare our typology against their eight mechanisms more in detail in Section 7.

Although this paper is devoted to psychological mechanisms (emotions, thoughts, and beliefs that can influence helping), these mechanisms can be used to elucidate why some situations, requests, or charity-appeals make people help more than others (the when-question), and also why some groups of people generally help more than others (the who-question; Bekkers \& Wiepking, 2011b; Piff et al., 2010; Wang, 2008; Wiepking \& Bekkers, 2012). 
Table 1: Examples of psychological mechanisms from each subcategory.

\begin{tabular}{|c|c|c|c|}
\hline $\begin{array}{l}\text { Overarching } \\
\text { categories } \\
\text { Subcategories }\end{array}$ & Examples of underlying & sychological mechanisms & $\begin{array}{l}\text { Corresponding mechanism } \\
\text { in Bekkers \& Wiepking's } \\
\text { framework }\end{array}$ \\
\hline & $\begin{array}{l}\text { Motivating } \\
\text { emotions/thoughts/beliefs: } \\
\text { ("I helped because....") }\end{array}$ & $\begin{array}{l}\text { Demotivating } \\
\text { emotions/thoughts/beliefs: } \\
\text { ("I did not help because...") }\end{array}$ & \\
\hline \multicolumn{4}{|l|}{ Emotions } \\
\hline \multirow[t]{2}{*}{ Emotional reactions } & $\begin{array}{l}\text { "...seeing the suffering made me } \\
\text { feel sad/sympathy/compassion } \\
\text { for the beneficiary" (empathic } \\
\text { concern) }\end{array}$ & & $\begin{array}{l}\text { (awareness of need) } \\
\text { (solicitation) } \\
\text { (altruism) }\end{array}$ \\
\hline & $\begin{array}{l}\text { "...seeing the suffering made me } \\
\text { feel sad/upset" (distress) }\end{array}$ & & \\
\hline Linked to entity & $\begin{array}{l}" \text {...I admire/respect the } \\
\text { beneficiary/requester" }\end{array}$ & $\begin{array}{l}\text { "...I am annoyed with/dislike the } \\
\text { beneficiary/requester" }\end{array}$ & $\begin{array}{l}\text { (awareness of need) } \\
\text { (solicitation) }\end{array}$ \\
\hline Incidental mood & $\begin{array}{l}" \text {...I received good news and } \\
\text { feel great today" }\end{array}$ & $\begin{array}{l}\text { "...I received bad news and feel } \\
\text { terrible today" }\end{array}$ & (awareness of need) \\
\hline \multicolumn{4}{|l|}{ Moral principles } \\
\hline Responsibility & $\begin{array}{l}" \text {..I was morally obliged to } \\
\text { help" (because of role, relation, } \\
\text { or situation) }\end{array}$ & $\begin{array}{l}\text { "...the beneficiaries were morally } \\
\text { obliged to help themselves" } \\
\text { "...someone else was/others were } \\
\text { morally obliged to help the } \\
\text { beneficiaries" }\end{array}$ & $\begin{array}{l}\text { (values) } \\
\text { (awareness of need) } \\
\text { (solicitation) }\end{array}$ \\
\hline Fairness & $\begin{array}{l}\text { "...not helping would be unfair } \\
\text { to someone" }\end{array}$ & $\begin{array}{l}\text { "...helping would be unfair to } \\
\text { someone" }\end{array}$ & (values) \\
\hline Not causing harm & & $\begin{array}{l}\text { "...helping would imply actively } \\
\text { harming someone" }\end{array}$ & (values) \\
\hline \multicolumn{4}{|l|}{ Anticipated impact } \\
\hline Self-efficacy & $\begin{array}{l}\text { "...my contribution would make } \\
\text { a significant difference for the } \\
\text { beneficiaries" }\end{array}$ & $\begin{array}{l}\text { "my contribution would not make } \\
\text { any difference for the } \\
\text { beneficiaries" }\end{array}$ & $\begin{array}{l}\text { altruism } \\
\text { (efficacy) } \\
\text { (solicitation) }\end{array}$ \\
\hline Response-efficacy & $\begin{array}{l}\text { "..this helping project/cause is } \\
\text { efficient/worthwhile/legitimate" }\end{array}$ & $\begin{array}{l}\text { "this helping project/cause is } \\
\text { inefficient/misguided/fake" }\end{array}$ & $\begin{array}{l}\text { efficacy } \\
\text { (altruism) } \\
\text { (solicitation) }\end{array}$ \\
\hline
\end{tabular}

\section{Anticipated personal consequences}

Material if helping

Material if not helping

Social if helping

Social if not helping

Emotional if helping

Emotional if not helping “...it will benefit me materially in the future"

"... I believed that I would get robbed if I did not help"

"...others will perceive me as kind-hearted or rich"

“...others would perceive me as cold-hearted or ungenerous if I did not help" "...helping makes me feel
happy/proud/meaningful"

"...not helping would make me feel guilty/ashamed/like a bad person"
"...I would not be able to pay the bills then"

“...I could travel more if I stopped helping"

"...others would see me as an irritating do-gooder if I helped"

"...not helping would signal my loyalty to my ingroup who dislikes the beneficiary"

"...helping would expose me to more suffering and increase expectations"

"...not helping would make me feel schadenfreude" costs/benefits

(solicitation)

costs/benefits

(solicitation)

reputation

(solicitation)

reputation

(solicitation)

psychological costs and benefits

(solicitation)

psychological costs and benefits

(solicitation) 


\section{Emotions}

Emotions, feelings, and affect have been intimately linked to moral attitudes and behavior in general (Greene et al., 2001; Haidt, 2001), and even stronger so to attitudes and behavior related to helping (van Kleef \& Lelieveld, 2021; Loewenstein \& Small, 2007; Slovic, 2007). Prosocial emotions are often strongly related to helping motivation and feeling more compassionate emotions is sometimes equalized to helping more.

Crucially, emotions can refer to many things in relation to helping. A person faced with a helping situation can help because: (1) she feels sad for the person in need (emotional reaction elicited by the need-situation); (2) she has affectionate emotions toward the beneficiary or the requester (emotions linked to a specific entity); (3) she is happy because of an unrelated event (incidental mood); (4) she desires the positive emotions that she expects as a result of helping (anticipated warm glow due to helping); (5) she wants to avoid the negative emotions that she expects as a result of not helping (anticipated guilt due to not helping). Moreover, other emotions involved in helping decisions can be (6) emotions, feelings, or attitudes toward the very act of helping, and (7) emotions that are experienced as a result of helping or non-helping.

An important feature of this typology is that it treats helping driven by experiencing an emotion, as different from helping driven by wanting to regulate one's emotions (Baumeister et al., 2007). Emotions of the first three types (emotional reactions, entity-linked emotions, and incidental mood) can influence helping simply by being experienced and are therefore included in the Emotioncategory. In contrast, Types 4 and 5 (anticipated emotions) represent emotion regulation strategies that are included in the anticipated personal consequences-category discussed later.

Type 6 (emotions towards helping) is almost indistinguishable from helping motivation, which is the proposed dependent variable, and therefore outside the scope of this article. ${ }^{3}$ Finally, Type 7 (emotions experienced after helping decision) is a consequence rather than an antecedent of helping - even if emotions felt as a response of an earlier helping decision can reinforce future helping by influencing one's mood (Aknin et al., 2012). Next, we explain and exemplify the three subcategories of emotions (Types 1-3 above).

\section{Emotional reactions felt as a response to a need situation}

Emotional reactions are immediately experienced emotions felt as a response to being exposed to a need situation (e.g. hearing a story about a child who is about to die from malnourishment). Some words used for describing these emotional reactions are empathic concern, empathic arousal, empathy, sympathy, pity, distress, tenderness, compassion, and sadness. Pinpointing the nuances between these are outside the scope of this article (see e.g. Batson, 2011; Cuff et al., 2016; Decety \& Cowell, 2014; Goetz et al., 2010), but one distinction should be clarified.

Empathic concern (also often referred to as sympathy; Small et al., 2007; Small, 2010; 2011) refers to the other-oriented emotion that is elicited by and congruent with the perceived welfare of someone else (Batson, 2011). ${ }^{4}$ Items for measuring empathic concern typically include sympathetic, warm, compassionate, softhearted, and touched (Dovidio et al., 2006). Distress refers to the negative inward-

\footnotetext{
${ }^{3}$ Some definitions of empathy, sympathy or compassion include a behavioral component (e.g. Betancourt, 1990; Goetz et al., 2010). Although people are free to define concepts as they like, we argue that including helping behavior as one part of the definition of emotions (or affect) begs the question when trying to determine the psychological mechanisms of helping.

${ }^{4}$ Note that empathic concern (feeling for the person in need) is sometimes used slightly different from empathy (feeling as the person in need; Cuff et al., 2016; Hein \& Singer, 2008; Zaki, 2014). Still, there are several studies that use the terms interchangeably (e.g. Pavey et al., 2012).
} 
directed feeling a helper might experience when seeing a need-situation. Distress is often measured with items such as worried, uneasy, distressed, and upset (Davis, 1983a, 1983b; Kogut \& Ritov, 2005a) but it can also include less aroused emotional reactions such as sad, downhearted, and depressed (Dovidio et al., 2006).

Both empathic concern and distress are emotions with negative valence that are typically experienced when learning about a need situation (Batson, 2011; Dickert \& Slovic, 2009). However, whereas distress is directed inwards (I feel bad), sympathy is directed outwards (I feel bad for the person in need). Sometimes, distress and empathic concern can motivate identical behaviors, but if there are alternative ways to feel better (such as switching channel to a comedy rather than keep watching the news), the person feeling distress is likely to do so whereas the person feeling empathic concern is not (Cialdini \& Kenrick, 1976).

Empathic concern clearly fits in the emotional reaction subcategory. Distress, on the other hand, can be categorized as either an emotional reaction, or as an anticipated personal consequence. This depends on whether the person believes that engaging in helping will reduce the personal distress or not. Helping as a result of feeling sad from hearing about a need-situation (an emotional reaction) is different from helping because one anticipates feeling better if one helps (a type of emotion regulation). Helping in order to avoid feeling bad, and helping in order to feel good, will be covered more in Section 6.

Many studies include one or several types of emotional reactions as a possible psychological mechanism underlying helping (e.g. Bagozzi \& Moore, 1994; Fisher \& Ma, 2014; Graziano et al., 2007; Kogut \& Ritov, 2005b; 2007; Pagano \& Huo, 2007; Pavey et al., 2012; Pfattheicher et al., 2020; Saito et al., 2019; Västfjäll, et al. 2014). Empathic concern has been found to predict helping rather well in many situations but less well in other situations. For example, in one study, native Germans and Turkish immigrants read either about Markus (a German) or Mohammed (a Turk) who had problems. When hearing about an in-group victim (but not when hearing about an out-group victim), empathic concern predicted helping motivation (Stürmer, et al., 2006; see also Maner \& Gailliot, 2007).

Empathic concern (and similar emotional reactions) has been suggested as the mediating psychological mechanism of both individual differences (e.g. on a group-level, women are more prone than men to feel and to express emotions when observing a need situation, Rueckert et al., 2011), and helping effects (e.g. people help identified beneficiaries more than statistical because a face and a name of a single person in need make us feel more empathic concern; Erlandsson et al., 2015; 2017).

\section{Emotions linked to a specific entity}

Not all emotions that influence helping behavior are elicited by the need-situation. Some emotions such as admiration, respect, attraction, and "aww" (the feeling of cuteness; Buckley, 2016), are linked to a specific entity (e.g. a person, an animal, or an organization). Unlike empathic concern and distress, these attitude-like emotions are present also in the absence of a need situation, but if an individual that we admire or find unusually cute is in need, the emotions elicited by the need situation are likely boosted to higher levels. In line with this, Batson (2011) argues that a perception of need together with valuing the beneficiary's welfare are necessary antecedents for empathic concern. Entity-linked emotions can be positive (e.g. respect, awe; Keltner \& Haidt, 2003), but also negative (e.g. anger or irritation; van Diepen et al., 2009; Fong, 2007), and thus both motivate and demotivate helping.

Liking of the beneficiary predicts helping for some types of helping. Cryder et al. (2017) suggest that people have an intuitive push towards helping more attractive beneficiaries. Relatedly, the research by Stürmer et al. (2005; 2006; Stürmer \& Snyder, 2010), found that whereas empathic concern was a stronger predictor of helping one's ingroup, liking and perceived attractiveness were stronger 
predictors of helping people from one's outgroup. Also, small details about beneficiaries' worldviews or prior behavior can increase as well as decrease their perceived attractiveness and consequently influence helping towards them (Gershon \& Fridman, 2020; Sole et al., 1975).

Entity-related emotions can be directed toward the beneficiary, but also toward the requester. Sometimes the beneficiary and the requester are the same (such as panhandling, or when an injured person screams for help), but often the requester and the beneficiary are different (such as when giving to a charitable organization). Physically attractive requestors made people donate more in a door-todoor fundraiser (Landry et al., 2006), and requestors who show gratitude (with kind words or smiles) will likely successfully solicit help also in the future, as emotions toward the requester become more positive (Merchant et al. 2010). A solicitation for help can also induce negative emotions toward the requester, if the solicitation is aggressive, annoying, or perceived as manipulative (Cotte et al., 2005; Hibbert et al., 2007). Requests such as "you simply have no choice - from a moral perspective you must help" can induce psychological reactance meaning that people feel that their free will is threatened, and stop helping in order to reinstate their sense of autonomy (Berkowitz, 1973; Dillard \& Shen, 2005; Quick, 2012; Reinhart et al., 2007).

\section{Incidental mood}

Emotions that are totally unrelated to the helping situation can also influence decisions to help (Anik et al., 2011; Carlson et al., 1988; Isen \& Levin, 1972; Small \& Lerner, 2008; Västfjäll et al., 2016). A positive mood makes it more likely that we notice need situations whereas a negative incidental mood makes us more self-focused. A happy mood makes us more energetic, approach-oriented and interested in others' well-being (Carlson et al., 1988; Dovidio et al., 2006; Frederickson, 2001; van Kleef \& Lelieveld, 2021), and when in a positive mood e.g. because one passed an exam, helping can be done as a way to "commemorate" one's personal success. Participants who are smiled at by an unrelated person tend to help more when seeing a need situation, possibly as a result of an improved mood (Guéguen \& de Gail, 2003), and an induced positive mood in combination with a high selfawareness has been suggested to increase helping (Berkowitz, 1987). In contrast, experiencing unrelated negative emotions (e.g. anger; Gummerum et al., 2016; van Kleef \& Lelieveld, 2021) or negative visceral states (e.g. hunger; Harel \& Kogut, 2014), makes people focus on their own suffering more than others' suffering.

Still, the finding that a positive mood increases (and that a negative mood decreases) helping is disputed. If a happy person needs to be exposed to a situation that will make her distressed, or if helping is costly, it is possible that she will refrain from helping in order to maintain her positive mood (Isen \& Simmonds, 1978; Sabato \& Kogut, 2021). Also, if a person in a negative mood believes that helping will make her feel better (due to an increased sense of meaningfulness or because of anticipated social or emotional benefits), she is more likely to help (Cunningham, 1990, Dovidio et al., 2006). These findings suggest that people in an incidental negative mood (as well as people experiencing personal distress from observing a need situation), sometimes help more because helping can be a way to regulate their emotions and improve their mood (c.f. the negative-state-relief model, Cialdini et al., 1987; Cialdini \& Fultz, 1990). This is surely an important motive, but helping to improve one's mood is future-focused and therefore included in the anticipated personal consequences-category, discussed in Section 6.

To say that emotions often motivate helping is not the same as to say that feeling more intense prosocial emotions necessarily make us help more. Also, it is not the same as to say that a change in helping is always a result of a change in emotions. In our conceptualization, emotions can increase even without a subsequent increase in helping, and helping can increase even without a preceding increase in emotions. We will now look at other psychological mechanisms that can motivate or demotivate helping. 


\section{Moral principles}

The second overarching category is based on perceived rules, obligations, and personal norms and here referred to as moral principles (Bekkers \& Ottoni-Wilhelm, 2016; Kouchaki et al., 2018; Schwartz \& Howard, 1984; Tomasello, 2020). Whereas the emotion-category includes mechanisms about "wanting to help", the mechanisms in the moral principle-category are more about "believing that one should help" (Cryder et al., 2017; Janoff-Bulman et al., 2009). Framed differently, moral principles illustrate a pressure-based prosocial motivation, as it implies helping, not primarily because one desires to help, but because one believes one is obliged to help (Gebauer et al., 2008; Pavey et al., 2012)..$^{5}$

Several types of moral principles are involved when making helping decisions. For instance, religious people might follow the decrees stated in their holy scriptures because they believe that they ought to. Likewise, many non-religious people are primarily motivated to abide the law, act justly, do their duty, not violate others' rights, and to "do the right thing" (Capraro \& Rand, 2018; Tappin \& Capraro, 2018). Loosely inspired by the moral foundation theory (Haidt, 2012; Nilsson et al., 2020; 2016), the three subcategories of moral principles are: (1) Responsibility, (2) Fairness, (3) Not causing harm.

\section{Responsibility}

Sometimes helping others is perceived as mandatory, so not helping implies that one has failed to fulfill one's moral responsibility. At other times, helping is over and above one's moral responsibility, and therefore optional (Leliveld et al. 2008; McManus et al., 2020). Responsibility in helping situations can refer to a causal responsibility (I caused the need-situation) or to a moral responsibility (I am responsible to help). We are primarily focusing on the latter, but causal responsibility is typically strongly related to moral responsibility. To exemplify; if someone is suffering because of my mistake, I will believe that I have an immense responsibility to rectify my mistake by helping, but if the same person is suffering because of her own mistake or because of someone else's mistake, my perceived personal responsibility to help will be weaker, and helping is less likely (Clayton et al., 2013; Henry et al., 2004). ${ }^{6}$ In one study where different costs of helping and different costs of not helping were tested as predictors of helping motivation, having caused the situation was the best predictor (Fritzsche et al., 2000).

There are also other types of contextual factors that can render a high perceived responsibility (Erlandsson et al., 2016b). For example, some occupations (a police officer or a nurse), or social roles (being an authority figure) come with an increased perceived responsibility (Haidt \& Baron, 1996; Jeske, 2008). Similarly, people feel a greater responsibility to help children, elderly, and kittens or puppies because they are perceived as vulnerable and defenseless whereas non-disabled adults are typically perceived to have a greater responsibility to take care of themselves (e.g. Back \& Lips, 1998; Chasteen \& Madey, 2003; Moche \& Västfjäll, 2021a).

Another factor that can increase our perceived responsibility to help is promise-making. We perceive ourselves to be more responsible to act when we have made a promise to do so, than if we have not (Kerr et al., 1997; Moriarty, 1975; Vanberg, 2008). To a lesser extent, just the mere existence of an expectation to receive support could increase the perceived personal responsibility to actually support (Goldstein et al., 2011; Nagatsu et al., 2018).

Importantly, perceived moral responsibility to help can be diluted by the mere presence of other potential helpers (i.e. the bystander effect; Cryder \& Loewenstein, 2012; D’Antonio, 2014; Darley \& Latane, 1968). In such a situation, the responsibility to help is perceived to be split between all bystanders meaning that the personal responsibility to help is smaller, than when one is the only

\footnotetext{
${ }^{5}$ Emotions (wanting to) and moral principles (believing that one is obliged to) can certainly co-occur, but they can also motivate helping independently.

${ }^{6}$ To say that a personal responsibility to help increases helping does not mean that it is necessary for helping. People do help also in situations when they think they are not obliged to.
} 
potential helper. One study found that people (no matter their own financial situation) believed that those richer than themselves had a responsibility to help more (Berman et al., 2020). Moreover, people in countries with a sophisticated welfare system tend to believe that the governments are responsible for providing health care and social services to those worse off, and consequently perceive a weaker personal responsibility to help (Nelson et al., 2006; Vamstad \& von Essen, 2013). Simply put, the amount of perceived responsibility can be understood as a zero-sum game, where an increased responsibility of others (the beneficiary or other potential helpers) decreases one's own responsibility to help.

Individual and cultural differences in perceived personal responsibility to help have been suggested as dispositional or cultural variables that determine people's motivation to engage in helping behavior (Baron \& Miller, 2000; Barrett et al., 2004; Schwartz \& Howard, 1980). To illustrate, Ottoni-Wilhelm and Bekkers (2010) suggest that the predictive power of dispositional empathy drops in magnitude and often loses significance after internalized moral principles about helping are controlled for (see also van der Linden, 2011), and Winterich and Zhang (2014) found that the main reason for people high on power-distance (those accepting inequalities) helping less is that their perceived personal responsibility to help is lower.

Perceived responsibility is frequently included in studies on helping, sometimes as a proxy for helping motivation (e.g. Jenni \& Loewenstein, 1997; Nagel \& Waldmann, 2012) but more often as a possible underlying mechanism of helping (e.g. Basil et al., 2006; Cameron \& Payne, 2011; Duval et al., 1979; Friedrich et al., 2005; Greitemeyer et al., 2006; Kleber et al., 2013; Lee et al., 2014). In our own research, we have found that perceived personal responsibility was the best mechanism for understanding the ingroup-effect (Erlandsson et al., 2015; 2017). We help ingroup beneficiaries (distant relatives and fellow countrymen) more than outgroup beneficiaries (non-relatives and foreigners) primarily because we believe that we have a personal responsibility to do so (see also Baron et al., 2013).

\section{Fairness}

Fairness is another moral principle that people care about and want to uphold, both on a procedural level and on an outcome level (Ajzen et al., 2000; Greenberg, 1987; Tyler, 2000). Most people value equality (equal outcomes) and to an even greater extent equity (equal outcomes to equal inputs), and both these concepts are closely linked to perceived fairness (Gordon-Hecker et al., 2017a; Shaw, 2013; Shaw \& Olson, 2012).

In prosocial situations, fairness-concerns can increase helping, for instance when helping improves the lives for those who are worse off, reduces inequalities, or when helping is provided to those who deserve it the most (Shaw \& Olson, 2012). Fairness-concerns can also decrease helping, when helping implies that one must give unequal treatment to two equally deserving beneficiaries, or when the beneficiaries one can help are extremely privileged (Bradley et al., 2019; Fehr \& Schmidt, 1999). People are even prepared to sacrifice efficiency by discarding resources, when they cannot help everyone equally much (Choshen-Hillel et al., 2015; Gordon-Hecker et al., 2017b; Shaw \& Knobe, 2013).

Another way that fairness-concerns influences helping is that people can feel obliged to help after learning that others have helped, in order to avoid unfair free-riding (Frey \& Meier, 2004; Goldstein et al., 2011; Trivers, 1971). To illustrate, an intervention intended to recruit blood donors with the help of making reciprocity norms salient involved first asking "Would you be willing to accept a transfusion if you needed one in the future" before asking "are you willing to donate blood?" (Landry, 2006). 
Research suggests that people value fairness in itself in anonymous situations, but that upholding fairness becomes even more important in public situations because an aversion towards appearing partial (Choshen-Hillel et al., 2015; Gordon-Hecker et al., 2017a; Shaw, 2013). Similarly, studies suggest that people are aversive towards unfair outcomes, but even more aversive towards the notion of being responsible for implementing unfairness (Beattie et al., 1994; Shaw \& Olson, 2014). For instance, people are more willing to create inequitable outcomes when they can let a random device determine which of two possible beneficiaries will be helped, than if they must make the decision themselves (Gordon-Hecker et al., 2017b). Helping or not helping in order to appear moral in the eyes of others will be discussed more in Section 6 .

\section{Not causing harm}

Moreover, people normally think that an omission to help is less morally bad than a helpful action that inadvertently cause harm to innocent bystanders. This is clearly illustrated in the classical sacrificial dilemmas that are often used in moral psychology (Bauman et al., 2014; Kahane et al., 2018). Some people prefer not to help five (or more) innocent people about to be run over by an out-of-control trolley, if helping implies killing one innocent person (especially if the killing implies physical force; Greene, 2008; 2013). This tendency can be explained by an internalized aversion towards causing harm that is stronger than the aversion towards allowing harm to happen (omission bias; e.g. Baron, 2008; Ritov \& Baron, 1990; 1999). Expressed differently, actively harming someone is equivalent to breaking a moral rule or violating a protected value, whereas omitting to help is normally more excusable (Baron \& Spranca, 1997; Janoff-Bulman et al., 2009; Krettenauer \& Johnston, 2011). This type of thinking sometimes makes people refrain from helping, not only when they know that helping will harm others, but also when there is uncertainty about possible side-effects of prosocial behavior (Anderson, 2003; Everett et al., 2015; Sunstein, 2005).

\section{Anticipated impact}

Whereas emotions and moral principles focused primarily on the past and on the present, the remaining two categories focus on the anticipated future consequences of helping decisions. Anticipated consequences for the beneficiaries (how will those in need be affected if I help?) will be discussed in this section whereas anticipated consequences for the helper (how will I be affected if I help?) will be discussed in Section 6.

Anticipated impact represents a more calculating psychological mechanism compared to emotions or moral principles, and concepts such as perceived impact, utility, effectiveness, efficiency and "making a difference" are all included in this category. People value effectiveness and efficiency when making decisions about themselves, but also when making decisions about others (Duncan, 2004), and help more when they can perceive that their help is improving the beneficiary's condition (Smith et al., 1989).

On the other hand, we are demotivated when we expect that our helping will not do any difference, or be a "drop in the bucket", and even more demotivated if we expect that helping will worsen the need situation. Anticipated impact is often measured next to some type of emotional reaction when trying to determine if a helping effect is driven by quick emotion-based System 1-like processes or by more calculative, reason-based System 2-like processes (Butts et al., 2019; Cameron \& Payne, 2011; Camilleri \& Larrick, 2019; Cryder, et al., 2013a; 2013b; Dickert et al., 2011b; Grant et al., 2007; Friedrich \& McGuire, 2010; Verkaik, 2016).

We distinguish two types of anticipated impact - Self-efficacy and Response-efficacy (e.g. Bandura, 1977; Basil et al., 2008; Block \& Keller, 1997; Sharma \& Morwitz, 2016). In a helping context, self- 
efficacy refers to the belief that "I am able to make a difference", whereas response-efficacy refers to a belief that "a difference can be made", or that a specific project or helping enterprise is effective and worthwhile.

\section{Self-efficacy}

Helpers who have a desire to personally make a difference are referred to as "Impact philanthropists". This desire can give rise to a preference to give directly to a homeless person rather than to an organization, or to a preference to devote one's helping effort to a small, clearly defined, cause (Caviola et al., 2020; Duncan, 2004; Lewis \& Small, 2019). The prospect of "fixing a small problem" once and for all is more appealing than the prospect of making an equally big contribution to a much larger problem, despite that the actual amount of good one can do is typically greater when focusing on large-scale problems (Li \& Chapman, 2009; Zhang \& Slovic, 2018). Likewise, people are the most likely to provide support when a fundraiser is close to its goal (e.g. we want to raise $\$ 10000$ and we have already obtained $90 \%$ of our goal), and this "goal gradient effect" has been linked to perceived self-efficacy (Cryder et al., 2013b; Kuppuswamy \& Bayus, 2017). Similarly, we found support for the notion that perceived impact mediates the proportion dominance effect. People are more motivated to rescue 10 out of 12 otters for $\$ 200$, than they are to rescue 10 out of 1000 otters for the same amount. The reason for this is that the anticipated impact is perceived to be higher when helping 10 out of 12 (83.3\%) than if helping 10 out of 1000 (1\%; Erlandsson et al., 2014; 2015; 2017).

A field study by Gneezy et al. (2014), showed that if a large sum of money is used to cover all administrative costs of a charity organization (implying that $100 \%$ of the subsequently donated money will reach the beneficiaries), donations from the public will increase more than if the large sum of money is used as seed money or as matching money (even if these ways to use money also increased helping; Cryder et al., 2013b; List, 2011). The authors suggested that this is because people perceive that the impact of their own contribution is greater when someone else has paid for all overhead costs.

\section{Response-efficacy}

Whereas an impact philanthropist is primarily interested in self-efficacy and in "making a personal difference", other impact-motivated helpers focus on response-efficacy, which means that they want to help in ways that are as effective as possible. Perceived response-efficacy (or outcome-efficacy) can differ as a function of charitable cause (some problems in the world are perceived as more alterable than others) or as a function of charitable organization (some organizations are perceived to be more competent than others). A higher perceived organizational effectiveness has been shown to increase helping motivation and non-profit organizations perceived as professional, credible, and trustworthy typically elicit more support (Jones, 2017; Sargeant \& Woodliffe, 2007).

On the contrary, organizations that have a relatively high overhead cost or reside in a fancy office space are perceived as wasteful and inefficient, whereas low overhead costs or modest salaries to employees are typically (often mistakenly) seen as evidence for an effective charity (Caviola et al., 2014; Newman et al., 2019; Portillo \& Stinn, 2018). Sending out a charity appeal in a gloss envelope with a printed color-picture to sporadic givers rendered fewer donations than an identical charity appeal in a blank simple envelope (Bekkers \& Crutzen, 2007). In another study, the efficiency of a charity organization (a 2-star rating or a 4-star rating from a homepage rating how efficiently charities use their money) increased the proportion of people who donated money by forfeiting a personal discount (Winterich \& Barone, 2011).

Importantly, anticipated, or perceived response-efficacy is not the same as actual response-efficacy. Due to framing effects and heuristics, we sometimes perceive effective helping as ineffective and vice versa (Slovic, 2007). The well-known effective altruism movement argues that people should maximize response-efficacy when making prosocial decision. However, rather than using crude heuristics (such 
as minimizing overhead costs, or as always giving to those worse off; e.g. Baron \& Szymanska, 2011; Sunstein, 2005), effective altruists are explicitly motivated to help in the ways that do the most good from an impartial and universal point of view, and devoted to using scientific methods to determine the anticipated response-efficacy of different helping behaviors in a more objective way (MacAskill, 2015; Singer, 2009; 2011; 2016).

Both types of efficacies can be linked to individual differences in trust in the charitable sector and more generally to social capital (Konrath \& Handy, 2018; Sargeant \& Lee, 2004). Some people have much confidence in charitable organizations whereas others are inherently skeptical. Also, some people believe that they have the resources and the ability to help in efficient ways, whereas others do not. One study investigating gender differences in volunteering found that women help primarily through emotional reactions and moral principles, whereas men's helping is motivated more through trust and social networks (i.e. an anticipated impact motive; Einolf, 2011). Other studies found that impact information increase helping only among the relatively educated (Verkaik, 2016), and among large prior donors (Karlan \& Wood, 2017).

\section{Anticipated personal consequences}

The final overarching category includes different types of anticipated consequences for the person faced with the helping decision (Dovidio et al., 2006). Anticipated consequences for oneself can be classified as positive (personal benefits due to helping), or negative (personal costs due to helping). In addition, both the benefits and the costs can be categorized as material (e.g. money), social (e.g. reputation) or emotional (e.g. well-being; Carlson \& Zaki, 2018; Kawamura et al., 2021). Moreover, when pondering on whether to help or not, people can anticipate not only the personal consequences if they help, but also the personal consequences if they do not help. Table 1 includes examples of the different (but related) subcategories of anticipated personal consequences that can influence helping decisions.

\section{Anticipated personal consequences that motivate helping}

\section{Anticipated positive material consequences due to helping}

People sometimes see helping as an investment in that a smaller personal cost now will pay back in the future because of reciprocity norms (Leimgruber, 2018; Trivers, 1971). Prosocial activities can be done to gain material benefits, for instance by boosting one's chances of being hired by adding volunteering activities to their resume (Handy et al., 2010). People might also help in order to be eligible for a tax deduction (Duquette, 2016), or to obtain a symbolic gift or a free health check when donating blood (Goette \& Stutzer, 2019).

\section{Anticipated negative material consequences due to not helping:}

It is possible to help primarily in order to avoid a greater material loss (e.g. being robbed) or even a physical loss (being assaulted). To exemplify, a person who encounters a stranger who behaves erratically in a deserted place, might lend his/her cell phone, or give $\$ 20$, in order to "tend and befriend" and reduce the risk of being the target of aggression (Taylor, 2006). There is also some evidence for "protective donations" meaning that some anticipate that "bad things happen to bad people" and help because they believe that a decision to not help might affect their "karma" and physical well-being negatively (Converse et al., 2012; Kogut \& Ritov, 2011b; Lerner, 1980). 


\section{Anticipated positive social consequences due to helping}

Even in the absence of any tangible benefits, people can help in order to expand their social network (meet new friends), or to receive praise and improve their reputation among others (Anderson et al., 2020; Exley, 2017; Milinski et al., 2002; Raihani \& Smith, 2015; Tosi \& Warmke, 2016). Helping is usually seen as a social norm, and as social norms get more important in the presence of others, people help more when they believe they are being observed (Caviola \& Faulmüller, 2014; Rayniers \& Bhalla, 2013; Solomon et al., 1981). For instance, people offer to volunteer more if they believe their decision is made in public rather than in private, and offering to volunteer (vs. not doing it) typically improves one's social reputation within the group (Bereczkei et al., 2007; Fisher \& Ackerman, 1998). ${ }^{7}$

Individual and situational factors influence anticipated social benefits of helping. Men help more when they believe they are being observed by an attractive female than if they believe they are being observed by a male or not observed by anyone (van Vugt \& Iredale, 2013, see also Landry et al., 2006). Similarly, helping can be used as a humble way to show others one's prosperity (Hardy \& van Vugt, 2006; Bagwell \& Bernheim, 1996). A person who gives away tens of thousands of dollars to help sick children, communicates both "I am a nice person" and "I am a rich person" to observers in general, and to potential romantic partners in particular.

\section{Anticipated negative social consequences due to not helping}

Whereas non-helping is rarely associated with material personal costs, it is often associated with social personal costs. A person who decides not to help when aware of a need situation runs the risk of being perceived as a callous and unsympathetic person by observers (Vonasch et al., 2018). People who find themselves in a public helping situation are often aware of this, and might therefore help in order to avoid the social condemnation or loss in reputation that they expect will follow if they do not help (Bradley et al., 2018). This type of helping can be referred to as "giving in", meaning that the helper prefers not to be asked but still helps in order to avoid the social costs associated with saying no (Cain et al., 2014; see also Andreoni et al., 2017; DellaVigna et al., 2012; Flynn \& Lake, 2008; Lin et al., 2016).

Helping in order to avoid negative social consequences (avoiding blame) is not the same as helping in order to obtain positive social consequences (approaching praise; Wiltermuth et al., 2010). Helping to avoid blame is typically done in situations where perceived external expectations are high (e.g. when the norm is to help; Cialdini et al., 1990), whereas helping to obtain praise is typically done in situations where helping is costly or perceived as extraordinary (Berman \& Silver; 2022; Wiepking \& Heijnen, 2011).

\section{Anticipated positive emotional consequences due to helping}

Most people can benefit personally from helping, also in the absence of any material or social benefits. Even helping that is performed totally in private, such as anonymously donating money to a charity fundraiser, can reward the helper by making her feel meaningful or self-satisfaction as a result of the prosocial act (Baumann et al., 1981; Cialdini \& Kenrick, 1976; Duclos \& Barasch, 2014; Moche \& Västfjäll, 2021; Williamson \& Clark, 1989). The positive emotion that is felt after a moral decision is often referred to as "warm glow" or "emphatic joy", and anticipating these positive emotions can

\footnotetext{
${ }^{7}$ It should be noted that people might help more in public than in private situations not through social image concerns, but through a motivation to inspire others to help as well (Engelen et al., 2018; Karlan \& McConnell, 2014; van de Ven et al., 2018). The motive to inspire others belongs in the anticipated impact category rather than in the anticipated personal consequences category (but the two motives can surely co-occur).
} 
motivate helping (Andreoni, 1990; Batson et al., 1991; Butts et al., 2019; Smith et al., 1989; Västfjäll et al., 2015).

A relevant finding is that material or social rewards associated with helping, tend to reduce the anticipated emotional rewards of helping (Mellström \& Johannesson, 2008; Rayniers \& Bhalla, 2013; Wang \& Tong, 2015). Consequently, helpers who are primarily motivated by anticipated emotional rewards, prefer non-incentivized helping done in private over incentivized helping done in public. Relatedly, people help more when a helping behavior is framed as a "charitable purchase" rather than as a "donation rewarded with a gift". The reason for this is that a "charitable purchase" is internally compared against other (non-charitable) purchases, which provides the helper with warm glow for doing something relatively moral. "Donation rewarded with a gift" is instead internally compared against other non-rewarded donations, thus not eliciting as much warm glow (Chao, 2017; Krishna, 2011; Savary et al., 2020; Zlatev \& Miller, 2016).

Another robust finding is that mechanisms in the anticipated impact category influence anticipated warm glow. Several studies have shown that when people believe that their helping is directed to credible and worthwhile causes or organizations (i.e. high response-efficacy), and when they believe that their personal effort is making a noticeable difference (i.e. high self-efficacy), they also experience (and anticipate to experience) more warm glow (Aknin et al., 2013; Cryder et al., 2013b; Keenan \& Gneezy, 2016).

\section{Anticipated negative emotional consequences due to not helping}

Just as anticipated warm glow (if one is helping) can motivate prosocial behavior, so can anticipated guilt (or other anticipated negative emotions or cognitions) in the case one would not help, motivate us to help even in the absence of any observers (Ahn et al., 2014; Basil et al., 2008; Elgaaied, 2012; Lindsey, 2005; Malti \& Krettenauer, 2013; Powell et al., 2012; Wang, 2011). ${ }^{8}$ People try to forecast their own emotional responses, and as we are more motivated to avoid the negative than to approach the positive (e.g. Rozin \& Royzman, 2001), we tend to adjust our behavior so that we avoid negative emotions as much as possible.

As with praise and blame, the helping situations that we anticipate will make us feel warm glow are different from the situations that we anticipate will make us feel guilt (Erlandsson et al., 2016b;

Krettenauer \& Johnston, 2011). Specifically, perceived moral principles predicts anticipated emotional consequences. We anticipate feeling guilt as a result of non-helping primarily in situations where we believe we are responsible to help, but anticipate feeling warm glow as a result of helping primarily when there is no external or internal pressure to help (c.f. Dunn et al., 2014).

\footnotetext{
${ }^{8}$ Guilt can motivate helping in different ways. Guilt can be understood as a form of distress if elicited by the need situation, or as a form of negative incidental mood if elicited by something unrelated to the need situation, and can then influence helping through the Emotion-category. Guilt can also be anticipated, such as when one is aware of a need-situation and ponders how one will feel as a result of helping or not helping. Anticipated guilt due to not helping predicts helping through the anticipated personal consequenses-category (Baumeister et al., 1994).
} 


\section{Anticipated personal consequences that demotivate helping}

\section{Anticipated negative material consequences due to helping}

The most obvious reason for deciding not to help is that helping typically comes with a cost (Ferguson et al., 2019; Kelting et al., 2918; Rubaltelli et al., 2020; Thaler, 1985). The material cost can be monetary (giving away money will reduce my disposable income), temporal (volunteering will take time from more enjoyable activities), physical (donating blood is painful), or psychological (living a carbon neutral life is boring). Some types of digital helping behaviors might also increase the risk of being scammed. All of these personal costs can be avoided simply by deciding not to help.

\section{Anticipated positive material consequences due to not helping}

This is a different framing of the abovementioned mechanism. If I opt out from my monthly $\$ 100$ donation to a charitable cause, I will have an additional $\$ 100$ to spend on myself or my family. Illustrated differently, people tend to help less when reminded of alternative (possibly more attractive) ways to spend their money (i.e. opportunity costs; Moche et al., 2020).

\section{Anticipated negative social consequences due to helping}

One robust finding in the existing moral impression formation literature is that helping is not unequivocally perceived in positive lights (Berman \& Silver, 2022; Cramwinckel et al., 2015; Critcher \& Dunning, 2011). At times, helping is perceived as a sign that the helper is either motivated for "the wrong reasons" or helps in order to put others in a bad light (Erlandsson et al., 2020b; Newman \& Cain, 2014; Raihani \& Power, 2021).

Derogatory terms such as "do-gooder" or "goodness-junkie" suggest that helping, at times, does not only "not improve", but even worsen the helper's reputation (Minson \& Monin, 2012; Monin, 2007; Monin et al., 2008; Silver et al., 2021). For example, although people like helpers and promisekeepers, they do not like those who help too much or those who exceed their promises (Gneezy \& Epley, 2014; Klein \& Epley, 2014; Pleasant \& Barclay, 2018).

To the extent people are aware of this, they might refrain from helping, if the helping is inherently public, and if they believe that helping is not the local norm (Jones \& Linardi, 2014). Similarly, when helping publicly, people are careful not to appear motivated by ulterior motives (Lin-Healy \& Small, 2012; Scopelliti et al., 2015), which can even result in less helping in some situations. In one study where participants could help a well-liked charity-organization by pressing on a button, performance was lower if participants also had (publicly known) egoistic incitements for pressing (Ariely et al., 2009, see also White \& Peloza, 2009). On the other hand, helping that comes with a high physical pain (e.g. pouring an ice bucket over oneself to raise awareness of a disease) are more socially and emotionally rewarding than pleasurable helping (e.g. a charity picnic; Gneezy et al., 2012; Olivola \& Shafir, 2013; 2018).

\section{Anticipated positive social consequences due to not helping:}

In circumstances involving intergroup animosity or beneficiaries from stigmatized groups, a potential helper seeing an outgroup member in need might help if the helping is made in private (e.g. because of empathic concern or moral principles), but refrain from helping when in public (Snyder et al., 1999). Both helping and non-helping can signal one's loyalty and group-belonging, and if I anticipate that non-helping will improve my status within the group, that could result in less helping. To exemplify, one study found that people dislike coworkers who act prosocially toward superiors (Vonk, 1998). Another found that people want to interact with people who "do their part" but not with those who behave extraordinary unselfish (Parks \& Stone, 2010), because extreme helpfulness can be perceived 
negatively as it sets undesired norms and make others look bad in comparison. To the extent that people are aware of this, they might consciously reduce their helping in some public situations.

\section{Anticipated negative emotional consequences due to helping}

Sometimes helping is emotionally difficult as it exposes oneself to needs and sufferings that one was previously blissfully unaware of (Cameron \& Payne, 2011; Kirby et al., 2019; Shaw et al., 1994). Also, agreeing to help once tends to increase the number of requests one will get in the future, and intensify expectations that one will continue to help henceforward. By committing to help someone in acute need, one also faces the risk of failure (e.g. a person dying while you are performing CPR), and this can be traumatic as well as reduce your self-confidence.

Again, people can predict these consequences, and anticipation of an increased exposure of suffering (with subsequent personal distress), of more requests and greater expectations to help, or a fear of not being able to help successfully can demotivate people from helping in the first place (Cameron et al., 2015). Providing indirect support for this mechanisms, one study gave donors the option to donate once and never be contacted again, and this increased subsequent donations not only in the short but also in the long term (Kamdar, et al., 2015).

\section{Anticipated positive emotional consequences due to not helping}

Although not a widespread mechanism, it is possible to imagine people who are in a position to help, but refrain from doing so because they anticipate pleasure from non-helping (c.f. schadenfreude; Leach et al., 2003).

\section{Our typology vs. Bekkers \& Wiepking's theoretical framework}

The current typology is much inspired by the seminal article by Bekkers and Wiepking (2011a, henceforth B\&W). Their interdisciplinary review of the charitable giving literature (up until 2007) was impressive and extremely comprehensive when it was published, and has been cited over 1400 times to date.

Our article is in no way intended to challenge $B \& W$ in regards of systematically reviewing the existing literature. Instead, our typology should be understood as an alternative way to categorize psychological mechanisms, that - unlike B\&W - clearly differentiates psychological mechanisms (the why-question), from situational aspects (the when-question) and individual differences (the whoquestion), that influence helping. To facilitate comparison, we next discuss each of B\&W's proposed mechanisms and how they relate to the categories and subcategories in the typology we put forward (see also Table 1).

\section{Costs/benefits, reputation, psychological costs \& benefits, and efficacy}

Four of the eight mechanisms in B\&W's framework are included in our typology as well. B\&W's "costs/benefits" refers to basically the same concept as "anticipated material personal consequences" in our typology. Likewise, their "reputation" corresponds to "anticipated social personal consequences", and their "psychological costs and benefits" is more or less identical to our "anticipated emotional personal consequences". Moreover, B\&W's "efficacy" seems to refer to the same thing as "anticipated impact" (specifically response-efficacy) in our typology. 


\section{Awareness of need}

We see awareness of need as a requirement for helping rather than a psychological mechanism that influence helping. Without noticing a situation and interpreting it as a need for help, it is impossible to experience the emotions, thoughts, or beliefs that are included in the typology. ${ }^{9}$

Still, one can argue that awareness can come in different degrees and that more awareness (elicited e.g. by an increased media coverage) is linked to increased helping. B\&W exemplify by suggesting that the more people know about a specific cause, or about a specific type of plight, the more likely they are to support the charitable cause that focuses on the underlying problem. For instance, people donate more to cancer research if they know people who suffered from cancer (Bennett, 2003; Small \& Simonsohn, 2008; Zagefka et al., 2013). Although it remains to be tested empirically, we suggest that both emotional reactions and moral principles might underlie this "personal-experience effect".

Emotional reactions could explain this effect because being reminded of, and learning more about a specific cause, or about the fate of a specified individual, elicit more emotions towards that cause, and makes emotions more difficult to "shake off". Likewise, studies show that emotional reactions toward beneficiaries possible to help are weakened by unrelated pictures or by knowledge about beneficiaries that cannot be helped, as these distractors divert attention away from the need situation and from the beneficiaries one can help (Dickert \& Slovic, 2009; Västfjäll et al., 2015).

Moral principles could also explain the personal-experience effect, because when someone you know is suffering from a specific illness, fighting that illness becomes a mission that one must engage in personally, whereas helping is optional for others (e.g. "It's my obligation to donate to Alzheimer research because my dad suffered from it, but if your brother died from cancer, you should focus on that").

\section{Solicitation}

B\&W's "solicitation" is, in our view, not a psychological mechanism but rather a situational aspect that influences helping. Soliciting help through a direct face-to-face request rather than with a letter typically increases helping, but this should be seen as a helping effect (the when-question), rather than a psychological mechanism (the why-question).

With that said, several of the psychological mechanisms in our typology can be used to explain why some types of solicitations elicit more helping than others. Anticipated social and emotional personal consequences surely play a big role - it is more costly (both reputationally and emotionally) to decline to help when solicited face-to-face as opposed to indirectly. Also, some charity-requests (e.g. those presenting one identified victim; Kogut \& Ritov, 2015; Lee \& Feeley, 2016) attempt to increase helping by eliciting compassionate emotions, whereas other requests attempt to elicit a high anticipated impact and increase helping that way (e.g. those emphasizing low overhead costs, e.g. Gneezy et al., 2014). Likewise, being solicited in aggressive or manipulative ways can reduce helping through the entity-linked emotions mechanism.

\footnotetext{
${ }^{9}$ Noticing the event and interpreting the event as requiring help are the first two steps in Latané and Darleys (1970) classical decision model of bystander intervention.
} 


\section{Altruism}

There exist many definitions of altruism, and B\&W seem to use altruism primarily in its "economic meaning", not in its "utilitarian meaning", nor in its "social psychological meaning". Altruism in economy is understood as something close to self-efficacy, meaning that people motivated by altruism want to make a substantial difference, and that helping by others may "crowd out" personal helping (because the personal impact of helping is then reduced, relatively speaking; Duncan, 2004).

An alternative way to understand altruism is to shift from self-efficacy (how much good can I do?), to response-efficacy (how much good can be done in total; Genc et al., 2020; Singer, 2015). This latter type of altruism is similar to the one proposed by the effective altruism movement that base their altruism on what the anticipated consequences of decisions are, in terms of utilitarian cost-benefit calculations. Despite their differences, both the economic (self-efficacy) and the utilitarian understanding of altruism (response-efficacy) are related to the anticipated impact category in our typology.

To complicate things further, altruism is used in a third way in social psychology. Specifically, Batson (2011) argues that the only altruistic motive for helping is empathic concern which is one type of emotional reaction that people can feel as a result of observing a need situation. Altruism, in this sense, is then related to emotions rather than to anticipated impact. Because of the multiple ways that the term "altruism" is used in the literature, we prefer not to include it at all in this typology. ${ }^{10}$

\section{Values}

Finally, B\&W's "values" is, in our view, not a psychological mechanism but rather an individual difference. Values (as well as worldviews and moral intuitions) are relatively stable traits originating from the helper, and B\&W note that they "... are difficult, if not impossible to manipulate... (p. 941)".

Still, to say that values illustrate individual differences does not prevent us from linking it to an intermediating psychological mechanism. We suggest moral principles as the best candidate because individual differences in stable values and worldviews are intimately linked to individual differences in moral principles. Whereas some people see their obligation to help as limited to when their near family and friends are in need, others have wider moral circles including unknown people far away and even non-human animals and future generations (Reed \& Aquino, 2003; Waytz et al., 2019). Still, moral principles such as perceived personal responsibility can also be influenced by situational factors (such as who caused the need-situation, societal roles, and the relation between helpers and beneficiaries). In short, perceived moral principles can explain both why some groups of people help more than others, and why some situations elicit more helping than others.

\footnotetext{
${ }^{10}$ See e.g. Batson (2011), Dovidio et al. (2006), and van Vugt \& van Lange (2006) for additional discussions about definitions of altruism.
} 


\section{How to test underlying psychological mechanisms of helping}

Throughout this article, we have treated psychological mechanisms as emotions, thoughts or beliefs that are truthfully self-reported when asked about people's motives for helping or not helping. To illustrate, Konrath and Handy (2018) developed the "Motives to Donate Scale" including 18 statements such as "I donate because I feel compassion toward people in need" or "Donating money to charities provides too much of a financial strain on me". ${ }^{11}$

An inherent problem with all types of self-reported prosocial motives is that people may not honestly report the motives for their helping decisions (Batson, 2011). Social desirability is especially a major concern when asking people to self-report whether anticipated personal consequences motivate them to help (e.g. "Giving to charities makes me feel powerful" in Konrath \& Handy, 2018). This is not only a problem when asking people to reveal their motives in public, but also in anonymous surveys because the stated reasons for helping can influence one's self-perception. Below, we suggest two methodological approaches for handling this problem.

\section{Manipulating the situation}

One way to avoid the problems with social desirability in self-reporting is to experimentally manipulate the anticipated costs and benefits of helping, and test if actual helping behavior change as a function of varying the independent variable.

To illustrate, anticipated material costs and benefits can be manipulated by varying the asking amount (e.g. $\$ 5$ or $\$ 50$ ), or by offering (or not offering) a compensation to those who help (e.g. Rubaltelli et al., 2020). Anticipated social consequences can be experimentally manipulated by letting people make their helping decisions, either in private (no observers) or in public (with observers), as well as manipulating the injunctive norm among the observers (do observers approve of helping or not; e.g. Andersson et al., 2020). Anticipated emotional costs due to not helping can be manipulated to some extent, e.g. by varying how potential helpers think they will feel after their decision (e.g. the misattribution paradigm; Gaertner \& Dovidio, 1977; Schroeder et al., 1988), by varying exposure to the person in need after the decision has been made (Batson et al., 1991; Toi \& Batson, 1982), or by varying the descriptive social norms (Batson et al., 1988; Andersson et al., 2021). Likewise, anticipated emotional benefits due to helping can be manipulated, e.g. by varying whether a blood donor anticipates receiving a heart-warming thank-you letter from the anonymous beneficiary or not. ${ }^{12}$

When experimentally manipulating the situation, it is vital to first conduct pilot studies or manipulation-checks to establish that the manipulation influences the self-reported psychological mechanism as intended. For example, participants' self-reported anticipated material cost of helping should be higher among those being asked to donate $\$ 50$ than among those asked to donate $\$ 5$. Moreover, the manipulation checks should test for both presence and absence of effects on the included mechanisms. To illustrate, a researcher who wants to experimentally manipulate anticipated social consequences (using a private/public manipulation), should first ask participants questions not

\footnotetext{
${ }^{11}$ Konrath and Handy suggested six subscales, and each can be linked to subcategories in out typology. Their "tax" and "constraints" illustrates anticipated material benefits and costs due to helping. Their "egoism" illustrates anticipated social and emotional benefits. Their "friends who donate" illustrates one type of anticipated social benefits. Their "trust" illustrates response-efficacy. Finally, their "altruism" includes items about emotional reactions, e.g. "because I feel compassion" but also about moral principles, e.g. "people should be willing to help others who are less fortunate".

12 The experimental approach can be used also for the three other psychological mechanisms. Instructions or charity appeals can be manipulated in order to increase emotional reactions (e.g. by varying perspective-taking instructions or by showing a very emotional picture), anticipated impact (e.g. by varying the size of the problem), or moral principles (e.g. by varying who caused the need-situation).
} 
only about the mechanism that the manipulation is intended to influence (anticipated social costs/benefits due to helping or not helping), but also about other mechanisms that the manipulation is not intended to influence. A good experimental manipulation will influence self-reports of the intended psychological mechanism significantly more than it influences self-reports of the other unintended mechanisms.

\section{Meaningful mediation analysis}

One popular way to test underlying psychological mechanisms is to test for mediation (Hayes, 2008; Montoya \& Hayes, 2017; Preacher \& Hayes, 2008). Mediation analyses can be conducted in both correlational and experimental designs by testing whether the independent variable (naturally occurring or manipulated) influence the dependent variable (some manifestation of helping), as a consequence of influencing a proposed intermediating variable (a measured psychological mechanism). If performed correctly, mediation can help us understand which underlying psychological mechanisms best explain why some people help more than others (who*why), and why some situations elicit more helping than others (when*why).

In a demonstration of the latter, the first author randomly assigned participants to read one version of a charitable advertisement, and to state their emotional reaction (e.g. "Do you feel strong empathic feelings toward the victim"), perceived impact (e.g. "How much good do you think you can do by donating money to this organization"), and perceived responsibly (e.g. "To what degree do you think you have a personal responsibility to donate money to this organization"). Participants subsequently expressed their helping intention, and all three mechanisms were then tested as possible mediators of three well-known helping effects (Erlandsson et al., 2015).

The results showed that each mechanism was the primary mediator of a specific helping effect. Specifically, the identified victim effect (helping more when the ad portrays a single identified child; e.g. Kogut \& Ritov, 2005a; 2005b; 2015; Slovic, 2007; Small \& Loewenstein, 2003) was mediated by emotional reactions but not by anticipated impact or moral principles. The proportion dominance effect (helping more when one can help a large proportion of those in need; e.g. Bartels, 2006; Bartels \& Burnett, 2011; Fetherstonhaugh et al., 1997; Kleber et al., 2013) was mediated only by anticipated impact. Finally, the ingroup effect (helping ingroup beneficiaries more than outgroup beneficiaries, e.g. Baron, 2009; Fiedler et al., 2018; James \& Zagefka, 2017; Levine et al., 2002; Levine \& Thompson, 2004) was significantly mediated by all three included mechanisms, but perceived responsibility was the significantly better mediator. ${ }^{13}$

\footnotetext{
${ }^{13}$ Arguably, mediation analyses are currently being used too routinely rendering some "meaningless mediations". A common practice is to propose and test a single underlying mechanism as a mediator, and draw strong inferences about the underlying psychological mechanisms based on a significant result (e.g. Brunel \& Nelson, 2000; Pfattheicher et al., 2020; Sabato \& Kogut, 2021; Syropoulos \& Markowitz, 2021; Zagefka, 2018;). This is especially problematic when the proposed mediator is either conceptually similar to the independent variable (it then represents a manipulation check, e.g. Croson et al., 2009), or conceptually or empirically similar to the dependent variable (e.g. Pavey et al., 2012; Kappes et al., 2013). A preferable approach is to test several possible underlying mechanisms (each distinct from the independent variable and from the dependent variable) and compare which of the mechanisms best explain the effect when controlling for shared variance (Erlandsson, 2014, see also Pieters, 2017 and Zhao et al., 2010 for additional advice about mediation analyses).
} 


\section{Conclusion}

In the current paper, we propose a new comprehensive typology that we hope will help other researchers synthesize and organize the various emotions, thoughts, and beliefs that have been shown to increase or decrease different types of helping behavior. Our typology consists of four overarching categories (emotions, moral principles, anticipated impact and anticipated personal consequences), and has been inspired by several other influential models and frameworks (e.g. Batson, 2011; Bekkers \& Wiepking, 2011a; Ferguson et al., 2020; Konrath \& Handy, 2018; van der Linden, 2011; Weber \& Lindemann, 2007).

We are aware that our typology might need refinement in the future, but we believe that the idea to conceptually disentangle the "why-question" of helping from the "when-question" and from the "whoquestion", will make it easier to evaluate and understand existing and future studies related to human prosociality. All of these questions are valuable in their own right (and even more valuable in combination), but it is problematic to draw inferences about underlying psychological mechanisms based only on observed individual differences or situational factors alone. We argue that it is fruitful to acknowledge that these factors can influence helping behavior through several different types of emotions, thoughts, and beliefs. 


\section{References}

Ahn, H.-K., Kim, H. J., \& Aggarwal, P. (2013). Helping fellow beings: Anthropomorphized social causes and the role of anticipatory guilt. Psychological Science, 0956797613496823.

Ajzen, I., Rosenthal, L. H., \& Brown, T. C. (2000). Effects of perceived fairness on willingness to pay. Journal of Applied Social Psychology, 30(12), 2439-2450. doi:10.1111/j.1559-1816.2000.tb02444.x

Aknin, L. B., Dunn, E. W., \& Norton, M. I. (2012). Happiness Runs in a Circular Motion: Evidence for a Positive Feedback Loop between Prosocial Spending and Happiness. Journal of Happiness Studies, 13(2), 347-355. doi:10.1007/s10902011-9267-5

Aknin, L. B., Dunn, E. W., Whillans, A. V., Grant, A. M., \& Norton, M. I. (2013). Making a difference matters: Impact unlocks the emotional benefits of prosocial spending. Journal of Economic Behavior \& Organization, 88, 90-95. doi:http://dx.doi.org/10.1016/j.jebo.2013.01.008

Anderson, C. J. (2003). The psychology of doing nothing: Forms of decision avoidance result from reason and emotion. Psychological Bulletin, 129(1), 139-166. doi:10.1037/0033-2909.129.1.139

Anderson, R. A., Crockett, M. J., \& Pizarro, D. A. (2020). A theory of moral praise. Trends in cognitive sciences, 24(9), 694703. doi:https://doi.org/10.1016/j.tics.2020.06.008

Andersson, P. A., Erlandsson, A., Västfjäll, D., \& Tinghög, G. (2020). Prosocial and moral behavior under decision reveal in a public environment. Journal of Behavioral and Experimental Economics, 87, 101561. doi:https://doi.org/10.1016/j.socec.2020.101561

Andersson, P. A., Erlandsson, A., \& Västfjäll, D. (2021). Norm avoiders: The effect of optional descriptive norms on charitable donations. Journal of Behavioral Decision Making.

Andreoni, J. (1990). Impure altruism and donations to public goods: A theory of warm-glow giving. The Economic Journal, 100(401), 464-477. doi:10.2307/2234133

Andreoni, J., Rao, J. M., \& Trachtman, H. (2017). Avoiding the ask: A field experiment on altruism, empathy, and charitable giving. Journal of Political Economy, 125(3), 625-653.

Anik, L., Aknin, L. B., Norton, M. I., \& Dunn, E. W. (2011). Feeling good about giving: The benefits (and costs) of selfinterested charitable behavior. In D. M. Oppenheimer \& C. Y. Olivola (Eds.), The Science of Giving. New York: Taylor \& Francis Group.

Ariely, D., Bracha, A., \& Meier, S. (2009). Doing good or doing well? Image motivation and monetary incentives in behaving prosocially. American economic review, 99(1), 544-555. doi: 10.1257/aer.99.1.544

Back, S., \& Lips, H. M. (1998). Child sexual abuse: Victim age, victim gender, and observer gender as factors contributing to attributions of responsibility. Child Abuse \& Neglect, 22(12), 1239-1252. doi:10.1016/S0145-2134(98)00098-2

Bagozzi, R. P., \& Moore, D. J. (1994). Public service advertisements: Emotions and empathy guide prosocial behavior. Journal of Marketing, 58(1), 56-70. doi:10.2307/1252251

Bagwell, L. S., \& Bernheim, B. D. (1996). Veblen effects in a theory of conspicuous consumption. The American economic review, 349-373.

Bandura, A. (1977). Self-efficacy: toward a unifying theory of behavioral change. Psychological review, 84(2), 191.

Baron, J. (2008). Thinking and deciding (4th ed.): New York, NY, US: Cambridge University Press.

Baron, J. (2009). Parochialism as a result of cognitive biases. Retrieved from https://papers.ssrn.com/sol3/papers.cfm?abstract_id=1331317

Baron, J., \& Miller, J. G. (2000). Limiting the scope of moral obligations to help: A cross-cultural investigation. Journal of Cross-Cultural Psychology, 31(6), 703-725. doi:10.1177/0022022100031006003

Baron, J., Ritov, I., \& Greene, J. D. (2013). The duty to support nationalistic policies. Journal of Behavioral Decision Making, 26(2), 128-138. doi:10.1002/bdm.768

Baron, J., \& Spranca, M. (1997). Protected values. Organizational Behavior and Human Decision Processes, 70(1), 1-16. doi:10.1006/obhd.1997.2690

Baron, J., \& Szymanska, E. (2011). Heuristics and biases in charity. In D. M. Oppenheimer \& C. Y. Olivola (Eds.), The Science of Giving: Experimental Approaches to the Study of Charity. (pp. 215-235): New York, NY, US: Psychology Press.

Barrett, D. W., Wosinska, W., Butner, J., Petrova, P., Gornik-Durose, M., \& Cialdini, R. B. (2004). Individual differences in the motivation to comply across cultures: The impact of social obligation. Personality and Individual Differences, 37(1), 19-31.

Bartels, D. M. (2006). Proportion dominance: The generality and variability of favoring relative savings over absolute savings. Organizational Behavior and Human Decision Processes, 100(1), 76-95. doi:10.1016/j.obhdp.2005.10.004

Bartels, D. M., \& Burnett, R. C. (2011). A group construal account of drop-in-the-bucket thinking in policy preference and moral judgment. Journal of Experimental Social Psychology, 47(1), 50-57. doi:10.1016/j.jesp.2010.08.003

Barth, M., \& Stürmer, S. (2016). Comparison of the Effects of Individual and Group-Level Perspective: Taking on Intergroup Reconciliation. Social Psychology, 47(6), 311-326. doi:10.1027/1864-9335/a000285

Basil, D. Z., Ridgway, N. M., \& Basil, M. D. (2006). Guilt appeals: The mediating effect of responsibility. Psychology and Marketing, 23(12), 1035-1054. doi:10.1002/mar.20145

Basil, D. Z., Ridgway, N. M., \& Basil, M. D. (2008). Guilt and giving: A process model of empathy and efficacy. Psychology and Marketing, 25(1), 1-23. doi:10.1002/mar.20200

Batson, C. D. (2011). Altruism in humans. New York, NY, US: Oxford University Press.

Batson, C. D., Batson, J. G., Slingsby, J. K., Harrell, K. L., Peekna, H. M., \& Todd, R. M. (1991). Empathic joy and the empathy-altruism hypothesis. Journal of Personality and Social Psychology, 61(3), 413-426. doi:10.1037/00223514.61.3.413 
Batson, C. D., Dyck, J. L., Brandt, J. R., Batson, J. G., Powell, A. L., McMaster, M. R., \& Griffitt, C. (1988). Five studies testing two new egoistic alternatives to the empathy-altruism hypothesis. Journal of Personality and Social Psychology, 55(1), 52-77. doi:10.1037/0022-3514.55.1.52

Bauman, C. W., McGraw, A. P., Bartels, D. M., \& Warren, C. (2014). Revisiting external validity: Concerns about trolley problems and other sacrificial dilemmas in moral psychology. Social and Personality Psychology Compass, 8(9), 536554. doi:10.1111/spc3.12131

Baumann, D. J., Cialdini, R. B., \& Kendrick, D. T. (1981). Altruism as hedonism: Helping and self-gratification as equivalent responses. Journal of Personality and Social Psychology, 40(6), 1039-1046. doi:10.1037/0022-3514.40.6.1039

Baumeister, R. F., Stillwell, A. M., \& Heatherton, T. F. (1994). Guilt: an interpersonal approach. Psychological Bulletin, 115(2), 243. doi:10.1037/0033-2909.115.2.243

Baumeister, R. F., Vohs, K. D., Nathan DeWall, C., \& Liqing Zhang. (2007). How emotion shapes behavior: Feedback, anticipation, and reflection, rather Than direct causation. Personality and Social Psychology Review, 11(2), 167-203. doi:10.1177/1088868307301033

Beattie, J., Baron, J., Hershey, J. C., \& Spranca, M. D. (1994). Psychological determinants of decision attitude. Journal of Behavioral Decision Making, 7(2), 129-144. doi:10.1002/bdm.3960070206

Bekkers, R., \& Crutzen, O. (2007). Just keep it simple: a field experiment on fundraising letters. International Journal of Nonprofit and Voluntary Sector Marketing, 12(4), 371-378. doi:10.1002/nvsm.293

Bekkers, R., \& Ottoni-Wilhelm, M. (2016). Principle of Care and Giving to Help People in Need. European Journal of Personality, 30(3), 240-257. doi:10.1002/per.2057

Bekkers, R., \& Wiepking, P. (2011a). A literature review of empirical studies of philanthropy: Eight mechanisms that drive charitable giving. Nonprofit and Voluntary Sector Quarterly, 40(5), 924-973.

Bekkers, R., \& Wiepking, P. (2011b). Who gives? A literature review of predictors of charitable giving part one: religion, education, age and socialisation. Voluntary Sector Review, 2(3), 337-365. doi:10.1332/204080511X6087712

Bekkers, R., \& Wiepking, P. (2011c). Testing mechanisms for philanthropic behaviour. International Journal of Nonprofit and Voluntary Sector Marketing, 16(4), 291-297. doi:10.1002/nvsm.428

Bennett, R. (2003). Factors underlying the inclination to donate to particular types of charity. International Journal of Nonprofit and Voluntary Sector Marketing, 8(1), 12-29. doi:10.1002/nvsm.198

Bereczkei, T., Birkas, B., \& Kerekes, Z. (2007). Public charity offer as a proximate factor of evolved reputation-building strategy: an experimental analysis of a real-life situation. Evolution and Human Behavior, 28(4), 277-284. doi:http://dx.doi.org/10.1016/j.evolhumbehav.2007.04.002

Berkowitz, L. (1973). Reactance and the unwillingness to help others. Psychological Bulletin, 79(5), 310-317. doi: $10.1037 / \mathrm{h} 0034443$

Berkowitz, L. (1987). Mood, self-awareness, and willingness to help. Journal of Personality and Social Psychology, 52(4), 721-729. doi:10.1037/0022-3514.52.4.721

Berman, J. Z., Bhattacharjee, A., Small, D. A., \& Zauberman, G. (2020). Passing the buck to the wealthier: Referencedependent standards of generosity. Organizational Behavior and Human Decision Processes, 157, 46-56.

Berman, J. Z., \& Silver, I. (2021). Prosocial behavior and reputation: When does doing good lead to looking good? Current Opinion in Psychology.

Betancourt, H. (1990). An attribution-empathy model of helping behavior: Behavioral intentions and judgments of helpgiving. Personality and Social Psychology Bulletin, 16(3), 573-591.

Bhati, A., \& Hansen, R. (2020). A literature review of experimental studies in fundraising. Journal of Behavioral Public Administration, 3(1).

Block, L. G., \& Keller, P. A. (1997). Effects of self-efficacy and vividness on the persuasiveness of health communications. Journal of Consumer Psychology, 6(1), 31-54.

Bradley, A., Lawrence, C., \& Ferguson, E. (2018). Does observability affect prosociality? Proceedings of the Royal Society B: Biological Sciences, 285(1875), 20180116.

Bradley, A., Lawrence, C., \& Ferguson, E. (2019). When the relatively poor prosper: the underdog effect on charitable donations. Nonprofit and Voluntary Sector Quarterly, 48(1), 108-127.

Brunel, F. F., \& Nelson, M. R. (2000). Explaining Gendered Responses to "Help-Self" and "Help-Others" Charity Ad Appeals: The Mediating Role of World-Views. Journal of Advertising, 29(3), 15-28. doi:10.1080/00913367.2000.10673614

Buckley, R. C. (2016). Aww: The emotion of perceiving cuteness. Frontiers in Psychology, 7, 1740.

Burnstein, E., Crandall, C., \& Kitayama, S. (1994). Some neo-Darwinian decision rules for altruism: Weighing cues for inclusive fitness as a function of the biological importance of the decision. Journal of Personality and Social Psychology, 67(5), 773-789. doi:10.1037/0022-3514.67.5.773

Burum, B., Nowak, M. A., \& Hoffman, M. (2020). An evolutionary explanation for ineffective altruism. Nature Human Behaviour, 1-13.

Butts, M. M., Lunt, D. C., Freling, T. L., \& Gabriel, A. S. (2019). Helping one or helping many? A theoretical integration and meta-analytic review of the compassion fade literature. Organizational Behavior and Human Decision Processes, 151, 16-33.

Cain, D. M., Dana, J., \& Newman, G. E. (2014). Giving versus giving in. The Academy of Management Annals, 8(1), 505533.

Cameron, C. D., Harris, L. T., \& Payne, B. K. (2015). The Emotional Cost of Humanity: Anticipated Exhaustion Motivates Dehumanization of Stigmatized Targets. Social Psychological and Personality Science. doi:10.1177/1948550615604453

Cameron, C. D., \& Payne, B. K. (2011). Escaping affect: How motivated emotion regulation creates insensitivity to mass suffering. Journal of Personality and Social Psychology, 100(1), 1-15. doi:10.1037/a0021643 
Camilleri, A. R., \& Larrick, R. P. (2019). The collective aggregation effect: Aggregating potential collective action increases prosocial behavior. Journal of Experimental Psychology: General, 148(3), 550.

Capraro, V., \& Rand, D. G. (2018). Do the right thing: Experimental evidence that preferences for moral behavior, rather than equity or efficiency per se, drive human prosociality. Judgment \& Decision Making, 13(1), 99-111.

Carlson, M., Charlin, V., \& Miller, N. (1988). Positive mood and helping behavior: A test of six hypotheses. Journal of Personality and Social Psychology, 55(2), 211-229. doi:10.1037/0022-3514.55.2.211

Carlson, R. W., \& Zaki, J. (2018). Good deeds gone bad: Lay theories of altruism and selfishness. Journal of Experimental Social Psychology, 75, 36-40.

Caviola, L., \& Faulmüller, N. (2014). Moral hypocrisy in economic games-how prosocial behavior is shaped by social expectations. Frontiers in Psychology, 5, 897.

Caviola, L., Faulmüller, N., Everett, J., Savulescu, J., \& Kahane, G. (2014). The evaluability bias in charitable giving: Saving administration costs or saving lives? Judgment and Decision Making, 9(4), 303-315.

Caviola, L., Schubert, S., \& Nemirow, J. (2020). The many obstacles to effective giving. Judgment and Decision Making, 15(2), 159-172.

Chao, M. (2017). Demotivating incentives and motivation crowding out in charitable giving. Proceedings of the National Academy of Sciences, 201616921.

Chasteen, A. L., \& Madey, S. F. (2003). Belief in a just world and the perceived injustice of dying young or old. OmegaJournal of Death and Dying, 47(4), 313-326.

Choshen-Hillel, S., Shaw, A., \& Caruso, E. M. (2015). Waste management: How reducing partiality can promote efficient resource allocation. Journal of Personality and Social Psychology, 109(2), 210-231.

Cialdini, R. B., \& Fultz, J. (1990). Interpreting the negative mood-helping literature via "mega"-analysis: A contrary view. Psychological Bulletin, 107(2), 210-214. doi:10.1037/0033-2909.107.2.210

Cialdini, R. B., \& Kenrick, D. T. (1976). Altruism as hedonism: A social development perspective on the relationship of negative mood state and helping. Journal of Personality and Social Psychology, 34(5), 907-914. doi:10.1037/00223514.34.5.907

Cialdini, R. B., Reno, R. R., \& Kallgren, C. A. (1990). A focus theory of normative conduct: Recycling the concept of norms to reduce littering in public places. Journal of Personality and Social Psychology, 58(6), 1015-1026. doi:10.1037/00223514.58.6.1015

Cialdini, R. B., Schaller, M., Houlihan, D., Arps, K., Fultz, J., \& Beaman, A. L. (1987). Empathy-based helping: Is it selflessly or selfishly motivated. Journal of Personality and Social Psychology, 52(4), 749-758. doi:10.1037/00223514.52.4.749

Clark, R. D., \& Word, L. E. (1974). Where is the apathetic bystander? Situational characteristics of the emergency. Journal of Personality and Social Psychology, 29(3), 279.

Clayton, S., Koehn, A., \& Grover, E. (2013). Making sense of the senseless: Identity, justice, and the framing of environmental crises. Social Justice Research, 26(3), 301-319.

Converse, B. A., Risen, J. L., \& Carter, T. J. (2012). Investing in Karma: When Wanting Promotes Helping. Psychological Science. doi: $10.1177 / 0956797612437248$

Cotte, J., Coulter, R. A., \& Moore, M. (2005). Enhancing or disrupting guilt: the role of ad credibility and perceived manipulative intent. Journal of Business Research, 58(3), 361-368.

Cramwinckel, F. M., van den Bos, K., \& van Dijk, E. (2015). Reactions to morally motivated deviance. Current Opinion in Psychology, 6, 150-156.

Critcher, C. R., \& Dunning, D. (2011). No good deed goes unquestioned: Cynical reconstruals maintain belief in the power of self-interest. Journal of Experimental Social Psychology, 47(6), 1207-1213.

Croson, R., Handy, F., \& Shang, J. (2009). Keeping up with the Joneses: The relationship of perceived descriptive social norms, social information, and charitable giving. Nonprofit Management and Leadership, 19(4), 467-489. doi: $10.1002 / \mathrm{nml} .232$

Cryder, C., Botti, S., \& Simonyan, Y. (2017). The Charity Beauty Premium: Satisfying Donors'"Want" Versus "Should" Desires. Journal of Marketing Research, 54(4), 605-618.

Cryder, C. E., \& Loewenstein, G. (2012). Responsibility: The tie that binds. Journal of Experimental Social Psychology, 48(1), 441-445. doi:10.1016/j.jesp.2011.09.009

Cryder, C. E., Loewenstein, G., \& Scheines, R. (2013a). The donor is in the details. Organizational Behavior and Human Decision Processes, 120(1), 15-23. doi:10.1016/j.obhdp.2012.08.002

Cryder, C. E., Loewenstein, G., \& Seltman, H. (2013b). Goal gradient in helping behavior. Journal of Experimental Social Psychology, 49(6), 1078-1083. doi:http://dx.doi.org/10.1016/j.jesp.2013.07.003

Cuff, B. M., Brown, S. J., Taylor, L., \& Howat, D. J. (2016). Empathy: A review of the concept. Emotion review, 8(2), 144153.

Cunningham, M. R., Shaffer, D. R., Barbee, A. P., Wolff, P. L., \& Kelley, D. J. (1990). Separate processes in the relation of elation and depression to helping: Social versus personal concerns. Journal of Experimental Social Psychology, 26(1), 13-33. doi:http://dx.doi.org/10.1016/0022-1031(90)90059-U

Cutler, J., \& Campbell-Meiklejohn, D. (2019). A comparative fMRI meta-analysis of altruistic and strategic decisions to give. NeuroImage, 184, 227-241. doi:https://doi.org/10.1016/j.neuroimage.2018.09.009

D'Antonio, J. (2013). The role of diffusion of responsibility, responsibility, and attitude in willingness to donate to a world hunger-related charity. International Review on Public and Nonprofit Marketing, 11(1), 1-11. doi:10.1007/s12208-0130104-x

Danioni, F., \& Barni, D. (2021). Value priorities, impression management and self-deceptive enhancement: Once again, much substance and a little bit of style. The Journal of social psychology, 161(2), 146-159. 
Darley, J. M., \& Latane, B. (1968). Bystander intervention in emergencies: Diffusion of responsibility. Journal of Personality and Social Psychology, 8(4), 377-383. doi:10.1037/h0025589

Davis, M. H. (1983a). The effects of dispositional empathy on emotional reactions and helping: A multidimensional approach. Journal of Personality, 51(2), 167-184. doi:10.1111/j.1467-6494.1983.tb00860.x

Davis, M. H. (1983b). Measuring individual differences in empathy: Evidence for a multidimensional approach. Journal of Personality and Social Psychology, 44(1), 113-126. doi:10.1037/0022-3514.44.1.113

Decety, J., \& Cowell, J. M. (2014). Friends or foes: Is empathy necessary for moral behavior? Perspectives on psychological science, 9(5), 525-537.

DellaVigna, S., List, J. A., \& Malmendier, U. (2012). Testing for altruism and social pressure in charitable giving. The Quarterly Journal of Economics, 127, 1-56. doi:10.1093/qje/qjr050

Dickert, S., Kleber, J., Peters, E., \& Slovic, P. (2011b). Numeracy as a precursor to pro-social behavior: The impact of numeracy and presentation format on the cognitive mechanisms underlying donation decisions. Judgment and Decision Making, 6(7), 638-650.

Dickert, S., Kleber, J., Västfjäll, D., \& Slovic, P. (2016). Mental imagery, impact, and affect: A mediation model for charitable giving. PloS one, 11(2), e0148274. doi:10.1371/journal.pone.0148274

Dickert, S., Sagara, N., \& Slovic, P. (2011a). Affective motivations to help others: A two-stage model of donation decisions. Journal of Behavioral Decision Making, 24(4), 361-376. doi:10.1002/bdm.697

Dickert, S., \& Slovic, P. (2009). Attentional mechanisms in the generation of sympathy. Judgment and Decision Making, 4(4), 297-306.

van Diepen, M., Donkers, B., \& Franses, P. H. (2009). Does irritation induced by charitable direct mailings reduce donations? International Journal of Research in Marketing, 26(3), 180-188.

Dillard, J. P., \& Shen, L. (2005). On the nature of reactance and its role in persuasive health communication. Communication Monographs, 72(2), 144-168. doi:10.1080/03637750500111815

Dovidio, J. F., Piliavin, J. A., Schroeder, D. A., \& Penner, L. (2006). The Social Psychology of Prosocial Behavior: Mahwah, NJ, US: Lawrence Erlbaum Associates Publishers.

de Dreu, C. K., Greer, L. L., Handgraaf, M. J., Shalvi, S., Van Kleef, G. A., Baas, M., . . Feith, S. W. (2010). The neuropeptide oxytocin regulates parochial altruism in intergroup conflict among humans. Science, 328(5984), 1408-1411.

de Dreu, C. K., Greer, L. L., Van Kleef, G. A., Shalvi, S., \& Handgraaf, M. J. (2011). Oxytocin promotes human ethnocentrism. Proceedings of the National Academy of Sciences, 108(4), 1262-1266.

Duclos, R., \& Barasch, A. (2014). Prosocial behavior in intergroup relations: How donor self-construal and recipient groupmembership shape generosity. Journal of Consumer Research, 41(1), 93-108. doi:10.1086/674976

Duncan, B. (2004). A theory of impact philanthropy. Journal of Public Economics, 88(9-10), 2159-2180. doi:10.1016/s00472727(03)00037-9

Dunn, E. W., Aknin, L. B., \& Norton, M. I. (2014). Prosocial spending and happiness: Using money to benefit others pays off. Current Directions in Psychological Science, 23(1), 41-47. doi:10.1177/0963721413512503

Duquette, N. J. (2016). Do tax incentives affect charitable contributions? Evidence from public charities' reported revenues. Journal of Public Economics, 137, 51-69.

Duval, S., Duval, V. H., \& Neely, R. (1979). Self-focus, felt responsibility, and helping behavior. Journal of Personality and Social Psychology, 37(10), 1769-1778. doi:10.1037/0022-3514.37.10.1769

Einolf, C. J. (2011). Gender differences in the correlates of volunteering and charitable giving. Nonprofit and Voluntary Sector Quarterly, 40(6), 1092-1112.

Elgaaied, L. (2012). Exploring the role of anticipated guilt on pro-environmental behavior - a suggested typology of residents in France based on their recycling patterns. Journal of Consumer Marketing, 29(5), 369-377. doi:doi:10.1108/07363761211247488

Engelen, B., Thomas, A., Archer, A., \& Van de Ven, N. (2018). Exemplars and nudges: Combining two strategies for moral education. Journal of moral education, 1-20.

Erlandsson, A. (2014). Underlying psychological mechanisms of helping effects: Examining the when $\times$ why of charitable giving. (Doctoral Dissertation). Lund University

Erlandsson, A. (2020). Hjälpdilemman: Beslutsfattande när man inte kan hjälpa alla i nöd. Statsvetenskaplig tidskrift, 122(4), 601-624. Retrieved from https://journals.lub.lu.se/st/article/view/22358/19939

Erlandsson, A. (2021a). Smittminskningsprosocialitet. Hjälpandets psykologi i en pandemi. Statsvetenskaplig tidskrift, 123(5). Retrieved from https://journals.lub.lu.se/st/article/view/23307/20730

Erlandsson, A. (2021b). Seven (weak and strong) helping effects systematically tested in separate evaluation, joint evaluation and forced choice. Judgment and Decision Making, 16(5), 1113-1154.

Erlandsson, A., Björklund, F., \& Bäckström, M. (2014). Perceived utility (not sympathy) mediates the proportion dominance effect in helping decisions. Journal of Behavioral Decision Making, 27(1), 37-47. doi:10.1002/bdm.1789

Erlandsson, A., Björklund, F., \& Bäckström, M. (2015). Emotional reactions, perceived impact and perceived responsibility mediate the identifiable victim effect, proportion dominance effect and in-group effect respectively. Organizational Behavior and Human Decision Processes, 127(0), 1-14. doi:10.1016/j.obhdp.2014.11.003

Erlandsson, A., Björklund, F., \& Bäckström, M. (2017). Choice-justifications after allocating resources in helping dilemmas. Judgment and Decision Making, 12(1), 60-80.

Erlandsson, A., Jungstrand, A., \& Västfjall, D. (2016b). Anticipated guilt for not helping and anticipated warm glow for helping are differently impacted by personal responsibility to help. Frontiers in Psychology, 7(1475). doi:10.3389/fpsyg.2016.01475

Erlandsson, A., Lindkvist, A., Lundqvist, K., Andersson, P. A., Dickert, S., Slovic, P., \& Västfjäll, D. (2020a). Moral preferences in helping dilemmas expressed by matching and forced choice. Judgment and Decision Making, 15(4), 452475 . 
Erlandsson, A., Nilsson, A., Tinghög, G., \& Västfjäll, D. (2018a). Bullshit-sensitivity predicts prosocial behavior. PloS one, 13(7), e0201474. doi:10.1371/journal.pone.0201474

Erlandsson, A., Nilsson, A., \& Västfjäll, D. (2018b). Attitudes and donation behavior when reading positive and negative charity appeals. Journal of Nonprofit \& Public Sector Marketing, 1-31. doi:10.1080/10495142.2018.1452828

Erlandsson, A., Västfjäll, D., Sundfelt, O., \& Slovic, P. (2016a). Argument-inconsistency in charity appeals: Statistical information about the scope of the problem decrease helping toward a single identified victim but not helping toward many non-identified victims in a refugee crisis context. Journal of Economic Psychology, 56, 126-140. doi:http://dx.doi.org/10.1016/j.joep.2016.06.007

Erlandsson, A., Wingren, M., \& Andersson, P. A. (2020b). Type and amount of help as predictors for impression of helpers. PloS one, 15(12), e0243808. doi:10.1371/journal.pone.0243808

Everett, J. A., Caviola, L., Kahane, G., Savulescu, J., \& Faber, N. S. (2015). Doing good by doing nothing? The role of social norms in explaining default effects in altruistic contexts. European Journal of Social Psychology, 45(2), 230-241.

Everett, J. A., Colombatto, C., Chituc, V., Brady, W. J., \& Crockett, M. (2020). The effectiveness of moral messages on public health behavioral intentions during the COVID-19 pandemic. doi:10.31234/osf.io/9yqs8

Exley, C. (2017). Incentives for prosocial behavior: The role of reputations. Management Science, 64(5), 2460-2471.

Fehr, E., \& Schmidt, K. M. (1999). A theory of fairness, competition, and cooperation. The Quarterly Journal of Economics, 114(3), 817-868.

Feiler, D. C., Tost, L. P., \& Grant, A. M. (2012). Mixed reasons, missed givings: The costs of blending egoistic and altruistic reasons in donation requests. Journal of Experimental Social Psychology, 48(6), 1322-1328.

Ferguson, E., Hill, A., Lam, M., Reynolds, C., Davison, K., Lawrence, C., \& Brailsford, S. R. (2020). A typology of blood donor motivations. Transfusion, 60(9), 2010-2020.

Ferguson, E., \& Lawrence, C. (2016). Blood donation and altruism: the mechanisms of altruism approach. ISBT Science Series, 11(S1), 148-157.

Ferguson, E., Zhao, K., O'Carroll, R. E., \& Smillie, L. D. (2019). Costless and costly prosociality: correspondence among personality traits, economic preferences, and real-world prosociality. Social Psychological and Personality Science, 10(4), 461-471.

Fetherstonhaugh, D., Slovic, P., Johnson, S., \& Friedrich, J. (1997). Insensitivity to the value of human life: A study of psychophysical numbing. Journal of Risk and Uncertainty, 14(3), 283-300. doi:10.1023/a:100774432639

Fiedler, S., Hellmann, D. M., Dorrough, A. R., \& Glöckner, A. (2018). Cross-national in-group favoritism in prosocial behavior: Evidence from Latin and North America. Judgment \& Decision Making, 13(1), 42-60.

Fisher, R. J., \& Ackerman, D. (1998). The effects of recognition and group need on volunteerism: A social norm perspective. Journal of Consumer Research, 25(3), 262-275. doi:10.1086/209538

Fisher, R. J., \& Ma, Y. (2014). The price of being beautiful: Negative effects of attractiveness on empathy for children in need. Journal of Consumer Research, 41(2), 436-450. doi:10.1086/676967

Flynn, F. J., \& Lake, V. K. B. (2008). If you need help, just ask: Underestimating compliance with direct requests for help. Journal of Personality and Social Psychology, 95(1), 128-143. doi:10.1037/0022-3514.95.1.128

Fong, C. M. (2007). Evidence from an experiment on charity to welfare recipients: Reciprocity, altruism and the empathic responsiveness hypothesis. The Economic Journal, 117(522), 1008-1024. doi:10.1111/j.1468-0297.2007.02076.x

Fredrickson, B. L. (2001). The role of positive emotions in positive psychology: the broaden-and-build theory of positive emotions. American psychologist, 56(3), 218.

Frey, B. S., \& Meier, S. (2004). Social comparisons and pro-social behavior: Testing" conditional cooperation" in a field experiment. American economic review, 94(5), 1717-1722.

Friedrich, J., Lucas, G., \& Hodell, E. (2005). Proportional reasoning, framing effects, and affirmative action: Is six of one really half a dozen of another in university admissions? Organizational Behavior and Human Decision Processes, 98(2), 195-215. doi:10.1016/j.obhdp.2005.06.002

Friedrich, J., \& McGuire, A. (2010). Individual differences in reasoning style as a moderator of the identifiable victim effect. Social Influence, 5(3), 182-201. doi:10.1080/15534511003707352

Fritzsche, B. A., Finkelstein, M. A., \& Penner, L. A. (2000). To help or not to help: Capturing individuals decision policies. Social Behavior and Personality: an international journal, 28(6), 561-578. doi:10.2224/sbp.2000.28.6.561

Gaertner, S. L., \& Dovidio, J. F. (1977). The subtlety of White racism, arousal, and helping behavior. Journal of Personality and Social Psychology, 35(10), 691-707. doi:10.1037/0022-3514.35.10.691

Gebauer, J. E., Riketta, M., Broemer, P., \& Maio, G. R. (2008). Pleasure and pressure based prosocial motivation: Divergent relations to subjective well-being. Journal of Research in Personality, 42(2), 399-420. doi:10.1016/j.jrp.2007.07.002

Genç, M., Knowles, S., \& Sullivan, T. (2020). In search of effective altruists. Applied Economics, 1-15.

Genevsky, A., Västfjäll, D., Slovic, P., \& Knutson, B. (2013). Neural underpinnings of the identifiable victim effect: Affect shifts preferences for giving. The Journal of Neuroscience, 33(43), 17188-17196. doi:10.1523/jneurosci.2348-13.2013

Gershon, R., \& Fridman, A. (2020). The Cost of Opposition: Harming our Own Rather than Helping our Opponent. Available at SSRN 3682145.

Gneezy, A., \& Epley, N. (2014). Worth keeping but not exceeding: Asymmetric consequences of breaking versus exceeding promises. Social Psychological and Personality Science, 5(7), 796-804.

Gneezy, A., Imas, A., Brown, A., Nelson, L. D., \& Norton, M. I. (2012). Paying to be nice: Consistency and costly prosocial behavior. Management Science, 58(1), 179-187.

Gneezy, U., Keenan, E. A., \& Gneezy, A. (2014). Avoiding overhead aversion in charity. Science, 346(6209), 632-635. doi:10.1126/science. 1253932

Goette, L., \& Stutzer, A. (2020). Blood donations and incentives: Evidence from a field experiment. Journal of Economic Behavior \& Organization, 170, 52-74. 
Goetz, J. L., Keltner, D., \& Simon-Thomas, E. (2010). Compassion: An evolutionary analysis and empirical review. Psychological Bulletin, 136(3), 351-374. doi:10.1037/a0018807

Goldstein, N. J., Griskevicius, V., \& Cialdini, R. B. (2011). Reciprocity by proxy: A novel influence strategy for stimulating cooperation. Administrative Science Quarterly, 56(3), 441-473.

Gordon-Hecker, T., Choshen-Hillel, S., Shalvi, S., \& Bereby-Meyer, Y. (2017). Resource allocation decisions: When do we sacrifice efficiency in the name of equity? In Interdisciplinary perspectives on fairness, equity, and justice (pp. 93-105): Springer.

Gordon-Hecker, T., Rosensaft-Eshel, D., Pittarello, A., Shalvi, S., \& Bereby-Meyer, Y. (2017). Not taking responsibility: Equity trumps efficiency in allocation decisions. Journal of Experimental Psychology: General, 146(6), 771-775. doi:10.1037/xge0000273

Grant, A. M., Campbell, E. M., Chen, G., Cottone, K., Lapedis, D., \& Lee, K. (2007). Impact and the art of motivation maintenance: The effects of contact with beneficiaries on persistence behavior. Organizational Behavior and Human Decision Processes, 103(1), 53-67.

Graziano, W. G., Habashi, M. M., Sheese, B. E., \& Tobin, R. M. (2007). Agreeableness, empathy, and helping: A person× situation perspective. Journal of Personality and Social Psychology, 93(4), 583.

Greenberg, J. (1987). Reactions to procedural injustice in payment distributions: Do the means justify the ends? Journal of Applied Psychology, 72(1), 55.

Greene, J. D. (2008). The secret joke of Kant's soul. In W. Sinnott-Armstrong (Ed.), Moral psychology, Vol 3: The neuroscience of morality: Emotion, brain disorders, and development. (pp. 35-80): Cambridge: MIT Press.

Greene, J. D. (2013). Moral tribes: Emotion, reason, and the gap between us and them: Penguin.

Greene, J. D., Sommerville, R. B., Nystrom, L. E., Darley, J. M., \& Cohen, J. D. (2001). An fMRI investigation of emotional engagement in moral judgment. Science, 293(5537), 2105-2108. doi:10.1126/science.1062872

Greitemeyer, T., Fischer, P., Kastenmüller, A., \& Frey, D. (2006). Civil courage and helping behavior: Differences and similarities. European Psychologist, 11(2), 90-98.

Guéguen, N., \& De Gail, M. A. (2003). The effect of smiling on helping behavior: Smiling and good Samaritan behavior. Communication Reports, 16(2), 133-140. doi:10.1080/08934210309384496

Gummerum, M., Van Dillen, L. F., Van Dijk, E., \& López-Pérez, B. (2016). Costly third-party interventions: The role of incidental anger and attention focus in punishment of the perpetrator and compensation of the victim. Journal of Experimental Social Psychology, 65, 94-104.

Haidt, J. (2001). The emotional dog and its rational tail: A social intuitionist approach to moral judgment. Psychological review, 108(4), 814-834. doi:10.1037/0033-295x.108.4.814

Haidt, J. (2012). The righteous mind: Why good people are divided by politics and religion: Vintage.

Haidt, J., \& Baron, J. (1996). Social roles and the moral judgement of acts and omissions. European Journal of Social Psychology, 26(2), 201-218. doi:10.1002/(sici)1099-0992(199603)26:2<201::aid-ejsp745>3.0.co;2-j

Handy, F., Cnaan, R. A., Hustinx, L., Kang, C., Brudney, J. L., Haski-Leventhal, D., . . Ranade, B. (2010). A cross-cultural examination of student volunteering: Is it all about résumé building? Nonprofit and Voluntary Sector Quarterly, 39(3), 498-523.

Harbaugh, W. T., Mayr, U., \& Burghart, D. R. (2007). Neural responses to taxation and voluntary giving reveal motives for charitable donations. Science, 316(5831), 1622-1625. doi:10.1126/science.1140738

Hardy, C. L., \& Van Vugt, M. (2006). Nice guys finish first: The competitive altruism hypothesis. Personality and Social Psychology Bulletin, 32(10), 1402-1413.

Harel, I., \& Kogut, T. (2015). Visceral needs and donation decisions: Do people identify with suffering or with relief? Journal of Experimental Social Psychology, 56, 24-29.

Hayes, A. F. (2008). Introduction to mediation, moderation, and conditional process analysis: A regression-based approach: Guilford Press.

Henry, P., Reyna, C., \& Weiner, B. (2004). Hate Welfare But Help the Poor: How the Attributional Content of Stereotypes Explains the Paradox of Reactions to the Destitute in America 1. Journal of Applied Social Psychology, 34(1), 34-58.

Hibbert, S., Smith, A., Davies, A., \& Ireland, F. (2007). Guilt appeals: Persuasion knowledge and charitable giving. Psychology and Marketing, 24(8), 723-742. doi:10.1002/mar.20181

Isen, A. M., \& Levin, P. F. (1972). Effect of feeling good on helping: cookies and kindness. Journal of Personality and Social Psychology, 21(3), 384.

Isen, A. M., \& Simmonds, S. F. (1978). The effect of feeling good on a helping task that is incompatible with good mood. Social Psychology, 346-349. doi:10.2307/3033588

James, T. K., \& Zagefka, H. (2017). The effects of group memberships of victims and perpetrators in humanly caused disasters on charitable donations to victims. Journal of Applied Social Psychology, 47(8), 446-458

Janoff-Bulman, R., Sheikh, S., \& Hepp, S. (2009). Proscriptive versus prescriptive morality: Two faces of moral regulation. Journal of Personality and Social Psychology, 96(3), 521-537. doi:10.1037/a0013779

Jenni, K., \& Loewenstein, G. (1997). Explaining the identifiable victim effect. Journal of Risk and Uncertainty, 14(3), 235257. doi:10.1023/a:1007740225484

Jeske, D. (2008). Special obligations. In E. N. Zalta (Ed.), The Stanford Encyclopedia of Philosophy (Fall 2008 ed.).

Jones, D., \& Linardi, S. (2014). Wallflowers: Experimental evidence of an aversion to standing out. Management Science, 60(7), 1757-1771.

Jones, D. B. (2017). Too much information? An experiment on communication and cooperation. Journal of Behavioral and Experimental Economics, 66, 29-39.

Kahane, G., Everett, J. A., Earp, B. D., Caviola, L., Faber, N. S., Crockett, M. J., \& Savulescu, J. (2018). Beyond sacrificial harm: A two-dimensional model of utilitarian psychology. Psychological review, 125(2), 131. 
Kamdar, A., Levitt, S. D., List, J. A., Mullaney, B., \& Syverson, C. (2015). Once and Done: Leveraging Behavioral Economics to Increase Charitable Contributions.". SPI Working paper Series, Nr 025.

Kappes, H. B., Sharma, E., \& Oettingen, G. (2013). Positive fantasies dampen charitable giving when many resources are demanded. Journal of Consumer Psychology, 23(1), 128-135.

Karlan, D., \& McConnell, M. A. (2014). Hey look at me: The effect of giving circles on giving. Journal of Economic Behavior \& Organization, 106, 402-412.

Karlan, D., \& Wood, D. H. (2017). The effect of effectiveness: Donor response to aid effectiveness in a direct mail fundraising experiment. Journal of Behavioral and Experimental Economics, 66, 1-8.

Kawamura, Y., Sasaki, S., \& Kusumi, T. (2021). Cultural similarities and differences in lay theories of altruism: Replication of Carlson and Zaki (2018) in a Japanese sample. Asian Journal of Social Psychology.

Keenan, E., \& Gneezy, A. (2016). Understanding and Overcoming Overhead Aversion in Charity. ACR North American Advances.

Kelting, K., Robinson, S., \& Lutz, R. J. (2019). Would you like to round up and donate the difference? Roundup requests reduce the perceived pain of donating. Journal of Consumer Psychology, 29(1), 70-78.

Keltner, D., \& Haidt, J. (2003). Approaching awe, a moral, spiritual, and aesthetic emotion. Cognition and Emotion, 17(2), 297-314. doi:10.1080/02699930302297

Kerr, N. L., Garst, J., Lewandowski, D. A., \& Harris, S. E. (1997). That still, small voice: Commitment to cooperate as an internalized versus a social norm. Personality and Social Psychology Bulletin, 23(12), 1300-1311. doi:10.1177/01461672972312007

Kirby, J. N., Seppälä, E., Wilks, M., Cameron, C. D., Tellegen, C. L., Nguyen, D. T., . . Martin, D. (2019). Positive and negative attitudes towards compassion predict compassionate outcomes. Current Psychology, 1-11.

Kleber, J., Dickert, S., Peters, E., \& Florack, A. (2013). Same numbers, different meanings: How numeracy influences the importance of numbers for pro-social behavior. Journal of Experimental Social Psychology, 49(4), 699-705. doi:10.1016/j.jesp.2013.02.009

van Kleef, G. A., \& Lelieveld, G.-J. (2021). Moving the Self and Others to Do Good: The Emotional Underpinnings of Prosocial Behavior. Current Opinion in Psychology.

Klein, N., \& Epley, N. (2014). The topography of generosity: Asymmetric evaluations of prosocial actions. Journal of Experimental Psychology: General, 143(6), 2366.

Kogut, T., \& Ritov, I. (2005a). The "Identified Victim" effect: An identified group, or just a single individual? Journal of Behavioral Decision Making, 18(3), 157-167. doi:10.1002/bdm.492

Kogut, T., \& Ritov, I. (2005b). The singularity effect of identified victims in separate and joint evaluations. Organizational Behavior and Human Decision Processes, 97(2), 106-116. doi:10.1016/j.obhdp.2005.02.003

Kogut, T., \& Ritov, I. (2007). "One of us": Outstanding willingness to help save a single identified compatriot. Organizational Behavior and Human Decision Processes, 104(2), 150-157. doi:10.1016/j.obhdp.2007.04.006

Kogut, T., \& Ritov, I. (2011). 'Protective donation': When refusing a request for a donation increases the sense of vulnerability. Journal of Experimental Social Psychology, 47(6), 1059-1069. doi:10.1016/j.jesp.2011.04.006

Kogut, T., \& Ritov, I. (2015). Target dependent ethics: discrepancies between ethical decisions toward specific and general targets. Current Opinion in Psychology, 6, 145-149.

Konrath, S., \& Handy, F. (2018). The Development and Validation of the Motives to Donate Scale. Nonprofit and Voluntary Sector Quarterly, 47(2), 347-375.

Kouchaki, M., Smith, I. H., \& Savani, K. (2018). Does deciding among morally relevant options feel like making a choice? How morality constrains people's sense of choice. Journal of Personality and Social Psychology.

Krettenauer, T., \& Johnston, M. (2011). Positively versus negatively charged moral emotion expectancies in adolescence: The role of situational context and the developing moral self. British Journal of Developmental Psychology, 29(3), 475488. doi:10.1348/026151010x508083

Krishna, A. (2011). Can supporting a cause decrease donations and happiness? The cause marketing paradox. Journal of Consumer Psychology, 21(3), 338-345. doi:http://dx.doi.org/10.1016/j.jcps.2011.02.001

Kuppuswamy, V., \& Bayus, B. L. (2017). Does my contribution to your crowdfunding project matter? Journal of Business Venturing, 32(1), 72-89.

Landry, C. E., Lange, A., List, J. A., Price, M. K., \& Rupp, N. G. (2006). Toward an understanding of the economics of charity: Evidence from a field experiment. The Quarterly Journal of Economics, 121(2), 747-782. doi:10.1162/qjec.2006.121.2.747

Landry, D. W. (2006). Voluntary reciprocal altruism: a novel strategy to encourage deceased organ donation. Kidney international, 69(6), 957-959.

Latané, B., \& Darley, J. M. (1970). The unresponsive bystander: Why doesn't he help? : Appleton-Century-Crofts.

Leach, C. W., Spears, R., Branscombe, N. R., \& Doosje, B. (2003). Malicious pleasure: Schadenfreude at the suffering of another group. Journal of Personality and Social Psychology, 84(5), 932-943. doi:10.1037/0022-3514.84.5.932

Lee, B. A., \& Farrell, C. R. (2003). Buddy, Can You Spare A Dime?: Homelessness, Panhandling, and the Public. Urban Affairs Review, 38(3), 299-324. doi:10.1177/1078087402238804

Lee, S., \& Feeley, T. H. (2016). The identifiable victim effect: a meta-analytic review. Social Influence, 11(3), 199-215. doi:10.1080/15534510.2016.1216891

Lee, S., Winterich, K. P., \& Ross, W. T. (2014). I'm moral, but I won't help you: The distinct roles of empathy and justice in donations. Journal of Consumer Research, 41(3), 678-696. doi:10.1086/677226

Leimgruber, K. L. (2018). The developmental emergence of direct reciprocity and its influence on prosocial behavior. Current Opinion in Psychology, 20, 122-126.

Leliveld, M. C., van Dijk, E., \& Van Beest, I. (2008). Initial ownership in bargaining: Introducing the giving, splitting, and taking ultimatum bargaining game. Personality and Social Psychology Bulletin, 34(9), 1214-1225. 
Lerner, M. J. (1980). The belief in a just world. In The Belief in a just World (pp. 9-30): Springer.

Levine, M., Cassidy, C., Brazier, G., \& Reicher, S. (2002). Self-categorization and bystander non-intervention: Two experimental studies. Journal of Applied Social Psychology, 32(7), 1452-1463. doi:10.1111/j.1559-1816.2002.tb01446.x

Levine, M., \& Thompson, K. (2004). Identity, place, and bystander intervention: Social categories and helping after natural disasters. The Journal of social psychology, 144(3), 229-245. doi:10.3200/socp.144.3.229-245

Lewis, J., \& Small, D. (2019). Ineffective Altruism: Giving Less When Donations Do More Good. Available at SSRN 3399121.

Li, M., \& Chapman, G. B. (2009). "100\% of anything looks good": The appeal of one hundred percent. Psychonomic Bulletin \& Review, 16(1), 156-162.

Lin, S. C., Schaumberg, R. L., \& Reich, T. (2016). Sidestepping the rock and the hard place: The private avoidance of prosocial requests. Journal of Experimental Social Psychology, 64, 35-40. doi:http://dx.doi.org/10.1016/j.jesp.2016.01.011

van der Linden, S. (2011). Charitable intent: A moral or social construct? A revised theory of planned behavior model. Current Psychology, 30(4), 355-374.

Lindsey, L. L. M. (2005). Anticipated guilt as behavioral motivation. Human Communication Research, 31(4), 453-481. doi:10.1111/j.1468-2958.2005.tb00879.x

Lin-Healy, F., \& Small, D. A. (2012). Cheapened altruism: Discounting personally affected prosocial actors. Organizational Behavior and Human Decision Processes, 117(2), 269-274. doi:10.1016/j.obhdp.2011.11.006

List, J. A. (2011). The market for charitable giving. Journal of Economic Perspectives, 25(2), 157-180.

Liu, W., \& Aaker, J. (2008). The happiness of giving: The time-ask effect. Journal of Consumer Research, 35(3), 543-557. doi:10.1086/588699

Loewenstein, G., \& Small, D. A. (2007). The Scarecrow and the Tin Man: The vicissitudes of human sympathy and caring. Review of general psychology, 11(2), 112-126. doi:10.1037/1089-2680.11.2.112

Lunn, P. D., Timmons, S., Belton, C. A., Barjaková, M., Julienne, H., \& Lavin, C. (2020). Motivating social distancing during the Covid-19 pandemic: An online experiment. Social Science \& Medicine, 113478.

MacAskill, W. (2015). Doing good better: Effective altruism and a radical new way to make a difference: Guardian Faber Publishing.

Malti, T., \& Krettenauer, T. (2013). The Relation of Moral Emotion Attributions to Prosocial and Antisocial Behavior: A Meta-Analysis. Child Development, 84(2), 397-412. doi:10.1111/j.1467-8624.2012.01851.x

Maner, J. K., \& Gailliot, M. T. (2007). Altruism and egoism: prosocial motivations for helping depend on relationship context. European Journal of Social Psychology, 37(2), 347-358. doi:10.1002/ejsp.364

Marsh, N., Marsh, A. A., Lee, M. R., \& Hurlemann, R. (2020). Oxytocin and the neurobiology of prosocial behavior. The Neuroscientist, 1073858420960111.

Mayr, U., Harbaugh, W. T., \& Tankersley, D. (2009). Neuroeconomics of charitable giving and philanthropy. In P. W. Glimcher, C. F. Camerer, E. Fehr, \& R. A. Poldrack (Eds.), Neuroeconomics: Decision making and the brain (pp. 303320). San Diego, CA, US: Elsevier Academic Press.

McManus, R. M., Kleiman-Weiner, M., \& Young, L. (2020). What we owe to family: The impact of special obligations on moral judgment. Psychological Science, 31(3), 227-242.

Mellström, C., \& Johannesson, M. (2008). Crowding out in blood donation: was Titmuss right? Journal of the European Economic Association, 6(4), 845-863.

Merchant, A., Ford, J. B., \& Sargeant, A. (2010). Charitable organizations' storytelling influence on donors' emotions and intentions. Journal of Business Research, 63(7), 754-762.

Milinski, M., Semmann, D., \& Krambeck, H. (2002). Donors to charity gain in both indirect reciprocity and political reputation. Proceedings of the Royal Society of London B: Biological Sciences, 269(1494), 881-883.

Minson, J. A., \& Monin, B. (2012). Do-gooder derogation: Disparaging morally motivated minorities to defuse anticipated reproach. Social Psychological and Personality Science, 3(2), 200-207.

Moche, H., Erlandsson, A., Andersson, D., \& Västfjäll, D. (2020). Opportunity Cost in Monetary Donation Decisions to Non-identified and Identified Victims. Frontiers in Psychology, 10(3035). doi:10.3389/fpsyg.2019.03035

Moche, H., \& Västfjäll, D. (2021a). Helping the child or the adult? Systematically testing the identifiable victim effect for child and adult victims. Social Influence, doi: 10.1080/15534510.2021.1995482

Moche, H., \& Västfjäll, D. (2021b). To give or to take money? The effects of choice on prosocial spending and happiness. The Journal of Positive Psychology, 1-12.

Monin, B. (2007). Holier than me? Threatening social comparison in the moral domain. Revue internationale de psychologie sociale, 20(1), 53-68.

Monin, B., Sawyer, P. J., \& Marquez, M. J. (2008). The rejection of moral rebels: Resenting those who do the right thing. Journal of Personality and Social Psychology, 95(1), 76-93. doi:10.1037/0022-3514.95.1.76

Montoya, A. K., \& Hayes, A. F. (2017). Two-condition within-participant statistical mediation analysis: A path-analytic framework. Psychological Methods, 22(1), 6-27. doi:http://dx.doi.org/10.1037/met0000086

Moriarty, T. (1975). Crime, commitment, and the responsive bystander: Two field experiments. Journal of Personality and Social Psychology, 31(2), 370.

Moseley, A., James, O., John, P., Richardson, L., Ryan, M., \& Stoker, G. (2018). The effects of social information on volunteering: A field experiment. Nonprofit and Voluntary Sector Quarterly, 47(3), 583-603.

Nagatsu, M., Larsen, K., Karabegovic, M., Székely, M., Mønster, D., \& Michael, J. (2018). Making good cider out of bad apples-Signaling expectations boosts cooperation among would-be free riders. Judgment and Decision Making.

Nagel, J., \& Waldmann, M. R. (2013). Deconfounding distance effects in judgments of moral obligation. Journal of Experimental Psychology: Learning, Memory, and Cognition, 39(1), 237-252. doi:10.1037/a0028641 
Nelson, M. R., Brunel, F. F., Supphellen, M., \& Manchanda, R. V. (2006). Effects of culture, gender, and moral obligations on responses to charity advertising across masculine and feminine cultures. Journal of Consumer Psychology, 16(1), 4556.

Newman, G. E., \& Cain, D. M. (2014). Tainted altruism: When doing dome good is evaluated as worse than doing no good at all. Psychological Science, 25(3), 648-655. doi:10.1177/0956797613504785

Newman, G. E., Shniderman, A., Cain, D. M., \& Sevel, K. (2019). Do the ends justify the means? The relative focus on overhead versus outcomes in charitable fundraising. Nonprofit and Voluntary Sector Quarterly, 48(1), 71-90.

Nilsson, A., Erlandsson, A., \& Västfjäll, D. (2016). The congruency between moral foundations and intentions to donate, self-reported donations, and actual donations to charity. Journal of Research in Personality, 65, 22-29. doi:10.1016/j.jrp.2016.07.001

Nilsson, A., Erlandsson, A., \& Västfjäll, D. (2020). Moral Foundations Theory and the Psychology of Charitable Giving. European Journal of Personality, n/a(n/a). doi:10.1002/per.2256

Nisbett, R. E., \& Wilson, T. D. (1977). Telling more than we can know: Verbal reports on mental processes. Psychological review, 84(3), 231.

Oceja, L. (2008). Overcoming empathy-induced partiality: Two rules of thumb. Basic and Applied Social Psychology, 30(2), 176-182. doi:10.1080/01973530802209236

Olivola, C. Y., \& Shafir, E. (2013). The martyrdom effect: When pain and effort increase prosocial contributions. Journal of Behavioral Decision Making, 26(1), 91-105. doi:10.1002/bdm.767

Olivola, C. Y., \& Shafir, E. (2018). Blood, sweat, and cheers: The martyrdom effect increases willingness to sponsor others' painful and effortful prosocial acts. Available at SSRN 3101447.

Oppenheimer, D., M, \& Olivola, C., Y (Eds.). (2011). The Science of Giving. New York: Taylor \& Francis Group.

Ottoni-Wilhelm, M., \& Bekkers, R. (2010). Helping behavior, dispositional empathic concern, and the principle of care. Social psychology quarterly, 73(1), 11-32. doi:10.1177/0190272510361435

Pagano, S. J., \& Huo, Y. J. (2007). The role of moral emotions in predicting support for political actions in post-war Iraq. Political psychology, 28(2), 227-255. doi:10.1111/j.1467-9221.2007.00563.x

Parks, C. D., \& Stone, A. B. (2010). The desire to expel unselfish members from the group. Journal of Personality and Social Psychology, 99(2), 303-310. doi:10.1037/a0018403

Pavey, L., Greitemeyer, T., \& Sparks, P. (2012). "I help because I want to, not because you tell me to": Empathy increases autonomously motivated helping. Personality and Social Psychology Bulletin, 38(5), 681-689. doi: $10.1177 / 0146167211435940$

Pfattheicher, S., Nockur, L., Böhm, R., Sassenrath, C., \& Petersen, M. B. (2020). The emotional path to action: Empathy promotes physical distancing and wearing of face masks during the COVID-19 pandemic. Psychological Science, 0956797620964422 .

Pieters, R. (2017). Meaningful mediation analysis: Plausible causal inference and informative communication. Journal of Consumer Research, 44(3), 692-716.

Piff, P. K., Kraus, M. W., Côté, S., Cheng, B. H., \& Keltner, D. (2010). Having less, giving more: The influence of social class on prosocial behavior. Journal of Personality and Social Psychology, 99(5), 771-784. doi:10.1037/a0020092

Pleasant, A., \& Barclay, P. (2018). Why hate the good guy? Antisocial punishment of high cooperators is greater when people compete to be chosen. Psychological Science, 29(6), 868-876.

Portillo, J. E., \& Stinn, J. (2018). Overhead aversion: Do some types of overhead matter more than others? Journal of Behavioral and Experimental Economics, 72, 40-50.

Powell, K. L., Roberts, G., \& Nettle, D. (2012). Eye Images Increase Charitable Donations: Evidence From an Opportunistic Field Experiment in a Supermarket. Ethology, 118(11), 1096-1101. doi:10.1111/eth.12011

Preacher, K. J., \& Hayes, A. F. (2008). Contemporary Approaches to Assessing Mediation in Communication Research. In A. F. Hayes, M. D. Slater, \& L. B. Snyder (Eds.), The SAGE Sourcebook of Advanced Data Analysis Methods for Communication Research (pp. 13-55). Thousand Oaks, CA: Sage Publications, Inc.

Preston, S. D., \& De Waal, F. B. (2002). Empathy: Its ultimate and proximate bases. Behavioral and Brain Sciences, 25(1), $1-20$.

Quick, B. L. (2012). What is the Best Measure of Psychological Reactance? An Empirical Test of Two Measures. Health Communication, 27(1), 1-9. doi:10.1080/10410236.2011.567446

Raihani, N., \& Power, E. A. (2021). No Good Deed Goes Unpunished: the social costs of prosocial behaviour.

Raihani, N. J., \& Smith, S. (2015). Competitive helping in online giving. Current Biology, 25(9), 1183-1186. doi:10.1016/j.cub.2015.02.042

Rayniers, D., \& Bhalla, R. (2013). Reluctant altruism and peer pressure in chartable giving. Judgment and Decision Making, $8(1), 7-15$.

Reed II, A., \& Aquino, K. F. (2003). Moral identity and the expanding circle of moral regard toward out-groups. Journal of Personality and Social Psychology, 84(6), 1270.

Reinhart, A. M., Marshall, H. M., Feeley, T. H., \& Tutzauer, F. (2007). The Persuasive effects of message framing in organ donation: The mediating role of psychological reactance. Communication Monographs, 74(2), 229-255. doi:10.1080/03637750701397098

Ritov, I., \& Baron, J. (1990). Reluctance to vaccinate: Omission bias and ambiguity. Journal of Behavioral Decision Making, 3(4), 263-277. doi:10.1002/bdm.3960030404

Ritov, I., \& Baron, J. (1999). Protected values and omission bias. Organizational Behavior and Human Decision Processes, 79(2), 79-94. doi:10.1006/obhd.1999.2839

Ross, L., \& Nisbett, R. E. (2011). The person and the situation: Perspectives of social psychology: Pinter \& Martin Publishers. 
Rozin, P., \& Royzman, E. B. (2001). Negativity bias, negativity dominance, and contagion. Personality and Social Psychology Review, 5(4), 296-320.

Rubaltelli, E., Hysenbelli, D., Dickert, S., Mayorga, M., \& Slovic, P. (2020). Asymmetric cost and benefit perceptions in willingness-to-donate decisions. Journal of Behavioral Decision Making, 33(3), 304-322.

Rueckert, L., Branch, B., \& Doan, T. (2011). Are gender differences in empathy due to differences in emotional reactivity? Psychology, 2(6), 574.

Sabato, H., \& Kogut, T. (2021). Happy to help—if it's not too sad: The effect of mood on helping identifiable and unidentifiable victims. PloS one, 16(6), e0252278.

Sachdeva, S., Jordan, J., \& Mazar, N. (2015). Green consumerism: moral motivations to a sustainable future. Current Opinion in Psychology, 6, 60-65. doi:http://dx.doi.org/10.1016/j.copsyc.2015.03.029

Saito, Y., Ueshima, A., Tanida, S., \& Kameda, T. (2019). How does social information affect charitable giving?: Empathic concern promotes support for underdog recipient. Social neuroscience, 14(6), 751-764.

Sargeant, A., \& Lee, S. (2004). Trust and relationship commitment in the United Kingdom voluntary sector: Determinants of donor behavior. Psychology and Marketing, 21(8), 613-635. doi:10.1002/mar.20021

Sargeant, A., \& Woodliffe, L. (2007). Gift giving: An interdisciplinary review. International Journal of Nonprofit and Voluntary Sector Marketing, 12(4), 275-307. doi:10.1002/nvsm.308

Savary, J., Li, C. X., \& Newman, G. E. (2020). Exalted purchases or tainted donations? self-signaling and the evaluation of charitable incentives. Journal of Consumer Psychology.

Schroeder, D. A., Dovidio, J. F., Sibicky, M. E., Matthews, L. L., \& et al. (1988). Empathic concern and helping behavior: Egoism or altruism? Journal of Experimental Social Psychology, 24(4), 333-353. doi:10.1016/0022-1031(88)90024-8

Schwartz, S. H., \& Howard, J. A. (1980). Explanations of the moderating effect of responsibility denial on the personal norm-behavior relationship. Social psychology quarterly, 43(4), 441-446. doi:10.2307/3033965

Schwartz, S. H., \& Howard, J. A. (1984). Internalized values as motivators of altruism. In Development and maintenance of prosocial behavior (pp. 229-255): Springer.

Scopelliti, I., Loewenstein, G., \& Vosgerau, J. (2015). You call it "Self-Exuberance"; I call it "Bragging" miscalibrated predictions of emotional responses to self-promotion. Psychological Science, 26(6), 903-914.

Sharma, E., \& Morwitz, V. G. (2016). Saving the masses: The impact of perceived efficacy on charitable giving to single vs. multiple beneficiaries. Organizational Behavior and Human Decision Processes, 135, 45-54. doi:http://dx.doi.org/10.1016/j.obhdp.2016.06.001

Shaw, A. (2013). Beyond "to share or not to share" The impartiality account of fairness. Current Directions in Psychological Science, 22(5), 413-417.

Shaw, A., \& Knobe, J. (2013). Not all mutualism is fair, and not all fairness is mutualistic. Behavioral and Brain Sciences, $36(1), 100$.

Shaw, A., \& Olson, K. (2014). Fairness as partiality aversion: The development of procedural justice. Journal of experimental child psychology, 119, 40-53.

Shaw, A., \& Olson, K. R. (2012). Children discard a resource to avoid inequity. Journal of Experimental Psychology: General, 141(2), 382 .

Shaw, L. L., Batson, C. D., \& Todd, R. M. (1994). Empathy avoidance: Forestalling feeling for another in order to escape the motivational consequences. Journal of Personality and Social Psychology, 67(5), 879-887. doi:10.1037/00223514.67.5.879

Silver, I., Newman, G., \& Small, D. A. (2021). Inauthenticity aversion: Moral reactance toward tainted actors, actions, and objects. Consumer Psychology Review, 4(1), 70-82.

Singer, P. (2009). The life you can save: Acting now to end world poverty. New York: Random House.

Singer, P. (2011). The Expanding Circle (2 ed.). Princeton, NJ: Princeton University Press.

Singer, P. (2016). Famine, Affluence, and Morality: Oxford University Press, USA.

Slovic, P. (2007). "If I look at the mass I will never act": Psychic numbing and genocide. Judgment and Decision Making, 2(2), 79-95.

Slovic, P., Västfjäll, D., Erlandsson, A., \& Gregory, R. (2017). Iconic photographs and the ebb and flow of empathic response to humanitarian disasters. Proceedings of the National Academy of Sciences, 114(4), 640-644. doi:10.1073/pnas.1613977114

Small, D. A. (2011). Sympathy biases and sympathy appeals: Reducing social distance to boost charitable contributions. In D. M. Oppenheimer \& C. Y. Olivola (Eds.), The Science of Giving: Experimental Approaches to the Study of Charity. New York: Taylor \& Francis Group.

Small, D. A., \& Lerner, J. S. (2008). Emotional policy: Personal sadness and anger shape judgments about a welfare case. Political psychology, 29(2), 149-168. doi:10.1111/j.1467-9221.2008.00621.x

Small, D. A., \& Loewenstein, G. (2003). Helping the victim or helping a victim: Altruism and identifiability. Journal of Risk and Uncertainty, 26(1), 5-16. doi:10.1023/a:1022299422219

Small, D. A., Loewenstein, G., \& Slovic, P. (2007). Sympathy and callousness: The impact of deliberative thought on donations to identifiable and statistical victims. Organizational Behavior and Human Decision Processes, 102(2), 143153. doi:10.1016/j.obhdp.2006.01.005

Small, D. A., \& Simonsohn, U. (2008). Friends of victims: Personal experience and prosocial behavior. Journal of Consumer Research, 35(3), 532-542. doi:10.1086/527268

Smith, K. D., Keating, J. P., \& Stotland, E. (1989). Altruism reconsidered: The effect of denying feedback on a victim's status to empathic witnesses. Journal of Personality and Social Psychology, 57(4), 641-650. doi:10.1037/0022-3514.57.4.641

Snyder, M., Omoto, A. M., \& Crain, A. L. (1999). Punished for their good deeds: Stigmatization of AIDS volunteers. American Behavioral Scientist, 42(7), 1175-1192. 
Sole, K., Marton, J., \& Hornstein, H. A. (1975). Opinion similarity and helping: Three field experiments investigating the bases of promotive tension. Journal of Experimental Social Psychology, 11(1), 1-13. doi:10.1016/S0022-1031(75)800047

Solomon, H., \& et al. (1981). Anonymity and helping. The Journal of social psychology, 113(1), 37-43.

Stürmer, S., \& Snyder, M. (Eds.). (2010). The Psychology of Prosocial Behavior. Chichester, UK: Wiley-Blackwell.

Stürmer, S., Snyder, M., Kropp, A., \& Siem, B. (2006). Empathy-motivated helping: The moderating role of group membership. Personality and Social Psychology Bulletin, 32(7), 943-956. doi:10.1177/0146167206287363

Stürmer, S., Snyder, M., \& Omoto, A. M. (2005). Prosocial Emotions and Helping: The Moderating Role of Group Membership. Journal of Personality and Social Psychology, 88(3), 532. doi:10.1037/0022-3514.88.3.532

Sunstein, C. R. (2005). Moral heuristics. Behavioral and Brain Sciences, 28(4), 531-573. doi:10.1017/s0140525x05000099

Syropoulos, S., \& Markowitz, E. M. (2021). Prosocial responses to COVID-19: Examining the role of gratitude, fairness and legacy motives. Personality and Individual Differences, 171, 110488.

Tappin, B. M., \& Capraro, V. (2018). Doing good vs. avoiding bad in prosocial choice: A refined test and extension of the morality preference hypothesis. Journal of Experimental Social Psychology, 79, 64-70.

Taylor, S. E. (2006). Tend and befriend: Biobehavioral bases of affiliation under stress. Current Directions in Psychological Science, 15(6), 273-277.

Thaler, R. (1985). Mental accounting and consumer choice. Marketing science, 4(3), 199-214.

Tobler, C., Visschers, V. H., \& Siegrist, M. (2012). Addressing climate change: Determinants of consumers' willingness to act and to support policy measures. Journal of Environmental Psychology, 32(3), 197-207.

Toi, M., \& Batson, C. D. (1982). More evidence that empathy is a source of altruistic motivation. Journal of Personality and Social Psychology, 43(2), 281-292. doi:10.1037/0022-3514.43.2.281

Tomasello, M. (2020). The moral psychology of obligation. Behavioral and Brain Sciences, 43, e56. doi:10.1017/S0140525X19001742

Tosi, J., \& Warmke, B. (2016). Moral Grandstanding. Philosophy \& Public Affairs, 44(3), 197-217.

Trivers, R. L. (1971). The evolution of reciprocal altruism. The Quarterly review of biology, 46(1), 35-57.

Tyler, T. R. (2000). Social justice: Outcome and procedure. International Journal of Psychology, 35(2), 117-125.

Vacondio, M., Priolo, G., Dickert, S., \& Bonini, N. (2021). Worry, Perceived Threat and Media Communication as Predictors of Self-Protective Behaviors During the COVID-19 Outbreak in Europe. Frontiers in Psychology, 12, 231.

Vamstad, J., \& von Essen, J. (2013). Charitable giving in a universal welfare state - Charity and social rights in Sweden. Nonprofit and Voluntary Sector Quarterly, 42(2), 285-301. doi:10.1177/0899764012466176

Vanberg, C. (2008). Why do people keep their promises? An experimental test of two explanations. Econometrica, 76(6), 1467-1480. doi:10.3982/ECTA7673

van de Ven, N., Archer, A. T., \& Engelen, B. (2018). More important and surprising actions of a moral exemplar trigger stronger admiration and inspiration. The Journal of social psychology, 1-15.

Verkaik, D. (2016). Do donors really care about impact information? A dual process account. Open Sci. Framework.

Vonasch, A. J., Reynolds, T., Winegard, B. M., \& Baumeister, R. F. (2018). Death before dishonor: Incurring costs to protect moral reputation. Social Psychological and Personality Science, 9(5), 604-613.

Vonk, R. (1998). The slime effect: Suspicion and dislike of likeable behavior toward superiors. Journal of Personality and Social Psychology, 74(4), 849-864. doi:10.1037/0022-3514.74.4.849

van Vugt, M., \& Iredale, W. (2013). Men behaving nicely: Public goods as peacock tails. British Journal of Psychology, 104(1), 3-13. doi:10.1111/j.2044-8295.2011.02093.x

van Vugt, M., \& van Lange, P. A. M. (2006). The altruism puzzle: Psychological adaptations for prosocial behavior. In M. Schaller, J. A. Simpson, \& D. T. Kenrick (Eds.), Evolution and social psychology. (pp. 237-261): Madison, CT, US: Psychosocial Press.

Västfjall, D., Slovic, P., Burns, W., Erlandsson, A., Koppel, L., Asutay, E., \& Tinghög, G. (2016). The arithmetic of emotion: Integration of incidental and integral affect in judgments and decisions. Frontiers in Psychology, 7. doi:10.3389/fpsyg.2016.00325

Västfjäll, D., Slovic, P., \& Mayorga, M. (2015). Pseudoinefficacy: Negative feelings from children who cannot be helped reduce warm glow for children who can be helped. Frontiers in Psychology, 6. doi:10.3389/fpsyg.2015.00616

Västfjäll, D., Slovic, P., Mayorga, M., \& Peters, E. (2014). Compassion fade: Affect and charity are greatest for a single child in need. PloS one, 9(6). doi:10.1371/journal.pone.0100115

Wang, C. L. (2008). Gender differences in responding to sad emotional appeal: A moderated mediation explanation. Journal of Nonprofit \& Public Sector Marketing, 19(1), 55-70. doi:10.1300/J054v19n01_03

Wang, X. (2011). The role of anticipated guilt in intentions to register as organ donors and to discuss organ donation with family. Health Communication, 26(8), 683-690. doi:10.1080/10410236.2011.563350

Wang, X., \& Tong, L. (2015). Hide the light or let it shine? Examining the factors influencing the effect of publicizing donations on donors' happiness. International Journal of Research in Marketing, 32(4), 418-424.

Wang, Y., Tang, Y.-Y., \& Wang, J. (2015). Cultural differences in donation decision-making. PloS one, 10(9), e0138219.

Warren, P. E., \& Walker, I. (1991). Empathy, effectiveness and donations to charity: Social psychology's contribution. British Journal of Social Psychology, 30(4), 325-337. doi:10.1111/j.2044-8309.1991.tb00949.x

Waytz, A., Iyer, R., Young, L., Haidt, J., \& Graham, J. (2019). Ideological differences in the expanse of the moral circle. Nature Communications, 10(1), 1-12.

Weber, E. U. (1998). From Shakespeare to Spielberg: Predicting selection among modes of decision making. Presidential address, annual meeting of the Society for Judgment and Decision Making. Dallas, TX.

Weber, E. U., Ames, D. R., \& Blais, A.-R. (2005). 'How do I choose thee? Let me count the ways': A textual analysis of similarities and differences in modes of decision-making in China and the United States. Management and Organization Review, 1(1), 87-118. doi:10.1111/j.1740-8784.2004.00005.x 
Weber, E. U., \& Lindemann, P. G. (2007). From intuition to analysis: Making decisions with our head, our heart, or by the book. In H. Plessner, C. Betsch, \& T. Betsch (Eds.), Intuition in Judgment and Decision making (pp. 191-208). Mahwah, NJ: Erlbaum.

Weyant, J. M. (1996). Application of compliance techniques to direct-mail requests for charitable donations. Psychology \& Marketing, 13(2), 157-170. doi:10.1002/(SICI)1520-6793(199602)13:2<157::AID-MAR3>3.0.CO;2-E

White, K., \& Peloza, J. (2009). Self-benefit versus other-benefit marketing appeals: Their effectiveness in generating charitable support. Journal of Marketing, 73(4), 109-124. doi:10.1509/jmkg.73.4.109

Wiepking, P., \& Bekkers, R. (2012). Who gives? A literature review of predictors of charitable giving. Part Two: Gender, family composition and income. Voluntary Sector Review, 3(2), 217-245. doi:10.1332/204080512X649379

Wiepking, P., \& Heijnen, M. (2011). The giving standard: conditional cooperation in the case of charitable giving. International Journal of Nonprofit and Voluntary Sector Marketing, 16(1), 13-22. doi:10.1002/nvsm.391

Williamson, G. M., \& Clark, M. S. (1989). Providing help and desired relationship type as determinants of changes in moods and self-evaluations. Journal of Personality and Social Psychology, 56(5), 722-734. doi:10.1037/0022-3514.56.5.722

Wiltermuth, S. S., Monin, B., \& Chow, R. M. (2010). The Orthogonality of Praise and Condemnation in Moral Judgment. Social Psychological and Personality Science, 1(4), 302-310. doi:10.1177/1948550610363162

Winterich, K. P., \& Barone, M. J. (2011). Warm glow or cold, hard cash? Social identity effects on consumer choice for donation versus discount promotions. Journal of Marketing Research, 48(5), 855-868. doi:10.1509/jmkr.48.5.855

Winterich, K. P., \& Zhang, Y. (2014). Accepting inequality deters responsibility: How power distance decreases charitable behavior. Journal of Consumer Research, 41(2), 274-293.

Zagefka, H. (2018). It could have been me: Proximity motivates disaster giving. International Journal of Nonprofit and Voluntary Sector Marketing, 23(1), e1587.

Zagefka, H., \& James, T. (2015). The Psychology of Charitable Donations to Disaster Victims and Beyond. Social Issues and Policy Review, 9(1), 155-192. doi:10.1111/sipr.12013

Zagefka, H., Noor, M., \& Brown, R. (2013). Familiarity breeds compassion: Knowledge of disaster areas and willingness to donate money to disaster victims. Applied Psychology, 62(4), 640-654. doi:10.1111/j.1464-0597.2012.00501.x

Zhang, Y., \& Slovic, P. (2018). Much ado about nothing: The zero effect in life-saving decisions. Journal of Behavioral Decision Making.

Zhao, X., Lynch, J. G., \& Chen, Q. (2010). Reconsidering Baron and Kenny: Myths and truths about mediation analysis. Journal of Consumer Research, 37(2), 197-206. doi:10.1086/651257

Zlatev, J. J., \& Miller, D. T. (2016). Selfishly benevolent or benevolently selfish: When self-interest undermines versus promotes prosocial behavior. Organizational Behavior and Human Decision Processes, 137, 112-122. doi:http://dx.doi.org/10.1016/j.obhdp.2016.08.004 